NBER WORKING PAPER SERIES

\title{
CONDITIONAL ASSET ALLOCATION \\ IN EMERGING MARKETS
}

Campbell R. Harvey

Working Paper No. 4623

\author{
NATIONAL BUREAU OF ECONOMIC RESEARCH \\ 1050 Massachusetts Avenue \\ Cambridge, MA 02138 \\ January, 1994
}

I appreciate the support of the Batterymarch fellowship and a grant from CIBER at the Fuqua School of Business, Duke University. Yoram Ehrlich, Chris Kirby and Akhtar Siddique provided excellent research assistance. This paper is part of NBER's research program in Asset Pricing. Any opinions expressed are those of the author and not those of the National Bureau of Economic Research. 
NBER Working Paper \#4623

January 1994

\title{
CONDITIONAL ASSET ALLOCATION
}

IN EMERGING MARKETS

\begin{abstract}
Within the context of conditional asset allocation strategies, this paper explores the implications of the low correlations of the emerging market returns with developed market returns and the relatively high degree predictability of emerging countries' returns. It is well known that low correlations improve investment opportunities and my research provides out-of-sample validation of the improved performance. However, the most dramatic enhancement is generated by the use of conditioning information. Portfolio strategies that use conditioning information to predict emerging market returns produce impressive out-of-sample performance over the 1980 1992 period.
\end{abstract}

Campbell R. Harvey

The Fuqua School of Business

Duke University

Durham, NC 27706

and NBER 


\section{Introduction}

In the 1980 's, fund managers realized that significant performance gains could be obtained with by diversifying into high quality global equity markets. However, these gains are limited by the fairly high cross-correlations returns in these markets.

While investment has traditionally been concentrated in developed markets, new interest has been sparked by the so-called 'emerging' capital markets. The emerging markets have at least three attractive qualities, two of which are their high average returns and their low correlations with developed markets. Diversification into these markets should result in higher expected returns and lower overall volatility.

In terms of portfolio theory, adding low correlation portfolios to an optimization enhances the reward to risk profile by shifting the mean-variance frontier to the left. However, this type of exercise may be misleading because it is based on ex post returns. This paper focusses on the performance of allocation strategies that optimize investment weights at the end of the month and hold the implied portfolio for the next month. Investment weights are then reoptimized and this strategy is continued throughout the 1980-1992 period.

However, the portfolio optimization problem requires important inputs - the expected returns and the variance-covariance matrix. In principal, all of these measures should be forward looking. That is, the returns, volatilities and correlations should be forecasted. The resulting investment strategy reflects current information.

The twist in this paper is that it utilizes the third desirable property of emerging market returns: they are predictable. Forecasting models are developed which provide one-step ahead forecasts for 41 markets (20 developed markets and 21 emerging markets). This is a much larger set of assets than the one considered in Solnik (1993).

Six portfolio strategies are evaluated. The first three examine traditional allocations based on (a) developed markets, (b) developed and emerging markets 
and (c) developed and emerging markets with a $20 \%$ cap on emerging markets. The allocations are traditional in that naive models, based on historical averages of the expected returns, variances and covariances, are used. For each case, two strategies are examined: (1) hold the global minimum variance portfolio and (2) hold the portfolio with a target volatility of $16 \%$ (annualized).

The fourth to sixth allocations use the same set of assets except conditioning information directly enters the optimization. With forecasted means, variances and covariances, new investment weights are calculated and the out-of-sample performance is evaluated and compared to the traditional asset allocation strategy.

Using the traditional asset allocation, there is some benefit to adding emerging markets to portfolios. However, the most dramatic enhancement comes with the introduction of emerging markets and conditioning information. Standard performance measures, such as ratios of expected return to volatility, show impressive performance when both emerging markets and conditioning information are used.

The paper is organized as follows. In the second section, the unconditional and conditional portfolio optimization strategies are presented. The data are presented in the third section. In the fourth part, the results of the out-of-sample portfolio allocation are evaluated. Some concluding remarks are offered in the sixth section.

\section{Portfolio Strategies}

\subsection{Unconditional asset allocation}

The usual problem that investment managers face is to maximize the expected returns of the portfolio subject to some target level of volatility. That is, investment weights are chosen to give the best possible performance for an expected level of standard deviation. The target standard deviation is determined outside the problem by the investor's tolerance for risk. 
The solution to this problem,

$$
\begin{aligned}
\max _{\mathbf{w}} & \mathbf{w}^{\prime} \boldsymbol{\mu} \\
\text { Subject to } \mathbf{w}^{\prime} \mathbf{V} \mathbf{w} & =\text { Target } \\
\mathbf{w}^{\prime} \mathbf{1} & =1
\end{aligned}
$$

where $\mathrm{w}$ represents a $N \times 1$ vector of investment proportions, $\mu$ is a $N \times 1$ vector of expected asset returns, $\mathrm{V}$ is a $N \times N$ variance-covariance matrix, and $N$ are the number of countries in the problem, is a standard quadratic program.

In this problem, the investment proportions are unrestricted in size but must sum to unity. This opens the possibility of extremely large short and long positions in any market. Given that thin trading is a problem in many emerging markets, it seem plausible that all short sales should be disallowed,

$$
w_{i} \geq 0 \quad \text { for } i=1, \ldots, N \text {. }
$$

This adds a third set of asset specific constraints to the problem (1).

The strategies evaluated in this paper involve solving (1) at the end of each month and holding the implied portfolio for the next month. The sample is updated using a 60-month moving window and the portfolio is reoptimized at each point in time. In all strategies, transactions costs are ignored although it is straightforward to modify the problem to add proportional transactions costs. All strategies are evaluated on an out-of-sample basis over the 1980.12 to 1992.06 period. That is, the first allocation is based on data from 1976:12 to 1980.11.

Two basic strategies are evaluated. The first is to choose the minimumvariance portfolio. That is, the investment weights match the weights implied by the minimum variance portfolio over the previous five years. These weights are used to form a portfolio and it is held over the next month. The second strategy involves choosing a portfolio with a target level of volatility of $16 \%$ (annualized). This volatility is roughly the volatility of holding the Morgan Stanley Capital International (MSCI) world market portfolio [see Harvey (1991)] which is a common benchmark.

In solving the problem, there is always a minimum-variance portfolio. However, there is not always a portfolio with the $16 \%$ target volatility because of the 
short-sales constraints. In the case where the $16 \%$ can not be attained from below, the maximum-variance portfolio is chosen. When the $16 \%$ cannot be attained from above (on the positively sloped section of the mean-variance frontier), the minimum-variance portfolio is chosen.

Three sets of equity groups are considered. The first restricts the assets to 21 equity markets in the MSCI universe. The second group adds 20 emerging equity markets from the International Finance Corporation. The third group includes the 41 countries but imposes the additional constraint to (1) and (2) that the sum of the weights in the emerging markets must be less than or equal to $20 \%$. This precludes the possibility that an unreasonable proportion of the portfolio is placed in emerging market assets.

The strategy is considered unconditional because of the way of expected returns, variances and covariances are chosen. The expected returns are the mean returns over the previous 60 months. Although these mean returns change through time as the 60-month window moves, using the average returns assumes that the best forecast of the equity return is its past average. This is consistent with a random walk model of stock prices with drift. This model implies that there is no other information relevant for forecasting next months stock price other than the previous price. In other words, stock returns are not predictable.

The unconditional strategy also places restrictions on other inputs to the problem. The variances and covariances are assumed to be the unconditional variances and covariances over the previous 60 months. This precludes the possibility that these measures move in more complex ways.

All strategies are developed and implemented in U.S. dollar terms. This assumes that no currency hedging takes place. Implementing the problem in local currency terms would be consistent with perfect foresight currency hedges being initiated for each country. This assumption is tenuous for developed markets and unreasonable for the emerging markets. As a result, the evaluation is done in a common numeraire currency. ${ }^{1}$

${ }^{1}$ Harvey (1993b) studies the international asset allocation problem and argues that the portfolio selection should include currency portfolios (in the form of local 


\subsection{Conditional asset allocation}

In the mean-variance problem in (1), three sets of inputs are needed: means, variances and covariances. At the end of the month, the investor is trying to design the portfolio that guarantees the highest possible expected return for the level of volatility that is consistent with the risk tolerance. In solving the unconditional problem, a set of portfolio weights are obtained that guarantees the highest ex post returns for a level of volatility - over the past five years. In other words, the unconditional mean-variance problem delivers a set of investment weights that 'work' - but only over the past history.

The only way for the manager to obtain an efficient portfolio (highest expected return for a level of volatility) in the unconditional problem is to hold the investment weights implied by the actual data! Suppose that a manager is being evaluated over the 1981.01 to 1985.12 period. In 1980.12 , the manager begins to manage the portfolio. Evaluation is measured in terms of how close the manager is to the efficient frontier. How can the manager obtain this efficient portfolio? - only on the basis of the knowing the data from 1981.01 to 1985.12 - which is obviously impossible.

In implementing the unconditional asset allocation strategies, managers will optimize their portfolio over 1976.01 to 1980.12 and hold the implied portfolio weights over the next period. These weights guarantee the portfolio is efficient over the 1976.01 to 1980.12 - not in the future.

So in practice, what is really required for the mean-variance problem is the best possible forecasts of the expected returns, variances and covariances for the next period. The past averages may not be that meaningful because the investment manager cares about the future and not the past. Past averages are only used if the means, variances and covariances are completely unpredictable.

The conditional asset allocation implements forecasting models for the inputs of the mean-variance problems. Linear regression models are built for the

deposits or loans). The solution to the quadratic program will deliver the optimal asset allocation as well as the optimal currency hedges. 
conditional means using a number of information variables,

$$
E\left[r_{i t} \mid Z_{t-1}\right]=Z_{t-1} \delta_{i}
$$

where $r_{i t}$ is the return on country $i$ over from $t-1$ to $t, Z_{t-1}$ is a $1 \times \ell$ vector of $\ell$ global and country specific information variables that are known at time $t-1$, $\delta_{i}$ is a $\ell \times 1$ coefficient matrix. The errors from this regression, $\epsilon_{i t}$, are assumed to be unrelated to the conditioning information, $Z_{t-1}$.

I use linear models for conditional means which is consistent with a number of previous studies. ${ }^{2}$ The forecasting variables include a constant as well as world variables such the lagged world dividend yield and lagged world returns and country-specific variables including lagged country dividend yield lagged country returns. All of the forecasting variables are financial variables to ensure data availability on the last day of the month.

The portfolio problem also requires the forecast of the variance-covariance matrix. Consider the covariance between asset $i$ and $j$ :

$$
\operatorname{Cov}\left[r_{i t}, r_{j t} \mid Z_{t-1}\right]=E\left[\left(r_{i t}-E\left[r_{i t} \mid Z_{t-1}\right]\right)\left(r_{j t}-E\left[r_{j t} \mid Z_{t-1}\right]\right) \mid Z_{t-1}\right] .
$$

Given the regression errors in (3), we can rewrite (4) as:

$$
\operatorname{Cov}\left[r_{i t}, r_{j t} \mid Z_{t-1}\right]=E\left[\epsilon_{i t} \epsilon_{j t} \mid Z_{t-1}\right]
$$

The conditional covariance is the forecasted value of the product of the residuals for the regression models for asset $i$ and asset $j$.

In principal, the conditioning information for asset $i$ and asset $j$ is different. In addition, the conditioning information on the product of the two residuals could be the intersection of the two information sets plus additional variables.

${ }^{2}$ See for example, Gibbons and Ferson (1985), Keim and Stambaugh (1986), Fama and French $(1988,1989)$, Harvey $(1989,1991)$, Ferson and Harvey (1991, 1993), Campbell and Hamao (1992), and Harvey (1993a) for some examples. Harvey (1992) compares the performance of linear models to general nonlinear alternatives and finds that linear models perform as well as nonlinear models in out-of-sample evaluation. 
For example, an autoregressive-conditional heteroskedasticity (ARCH) type model would include lagged values of the product of the residuals in the information set.

The approach of this paper is to use the unconditional mean of the product of the residuals as the forecasted variance-covariance matrix. This implicitly assumes that the product of the residuals is not predictable. This follows, in spirit, the approach of Solnik (1993). However, the matrix used in this paper is not the unconditional variance-covariance matrix. It is the average conditional variancecovariance matrix. Importantly, the $\boldsymbol{Z}_{t-1}$ variables are allowed to affect the means.

This approach greatly simplifies the estimation. Indeed, a full model of the variance-covariance matrix would require up to 820 forecasting equations when 41 markets are examined! In addition, the most important inputs for asset allocation are the expected values for the asset returns. The optimal weights are much more sensitive to a change in the means than to a change in the variances or covariances.

Similar to the unconditional asset allocation, the variance-covariance matrix is based on a 60-month moving window average of the product of the regression residuals through the sample. In the analysis, the regressions are estimated over the full sample which implies that the regression coefficients, $\delta_{i}$, are constant. More elaborate models which using moving-window estimation for the conditional means are also possible. This would allow for out-of-sample forecasts at every step. $^{3}$

In addition, to minimize the data snooping problem, a set of predetermined information variables were chosen before the data were examined. While the set of information variables resembles the set of variables used in potentially datasnooped studies of developed markets, no one has examined the predictability of emerging market returns. In addition, given the low correlations between emerging returns and developed returns, it does not necessarily follow that the variables that predict developed market returns automatically predict emerging market returns.

There is also the issue of survivorship biases in the emerging markets data

${ }^{3}$ Harvey (1989) and Solnik (1993) examine the out-of-sample forecasts of the linear regression models and find that their performance compares favorably to the in-sample forecasts. 
which is examined in Harvey (1993a). The International Finance Corporation began publishing indices in 1981 - yet their data reaches back to 1975.12. In some of the markets, the indices were back-tracked. This induces a look-back bias in the sample. That is, the stocks in 1976 are the ones that survived to 1981. Harvey argues that it is not clear that this problem is serious. In addition, the asset allocation routine avoids the look-back by requiring that the market exist for five years before it is included in the allocation.

\section{Data}

\subsection{Sources and summary statistics}

Data are available on for 21 developed markets from Morgan Stanley Capital International and 20 emerging markets from the International Finance Corporation of the World Bank. Some summary statistics are presented in table 1.

The summary statistics are presented for the full sample period, 1976.01 to 1992.06 and for a recent subperiod, 1985.01 to 1992.06. Both U.S. dollar returns and local currency returns are displayed. The statistics include the average (annualized) arithmetic and geometric return, standard deviation and autocorrelations. The developed market summary statistics are presented over different samples by other authors and appear for the purpose of comparison with the emerging returns.

The mean U.S. dollar returns for the emerging markets range from $72 \%$ (Argentina) to $-6 \%$ (Indonesia whose sample only begins in January 1990). This sharply contrasts with the range of average returns in the developed markets. In the MSCI sample, no country has an average arithmetic return that exceeds $25 \%$. In the IFC emerging sample, 9 countries (Argentina, Chile, Colombia, Philippines, Portugal, Taiwan, Thailand, Turkey and Venezuela) have returns that average above $25 \%$.

It is important to present both the arithmetic and geometric average returns. The geometric average reflects the average returns to a buy and hold strategy. 
With high volatility, there could be large differences in the arithmetic and geometric mean returns. This is especially evident in the emerging markets sample. The most dramatic example is Argentina. The arithmetic average return is $72 \%$ and the geometic average is $27 \%$ !

The emerging market returns are characterized by high volatility. Volatility ranges from $18 \%$ (Jordan) to $105.6 \%$ (Argentina). In contrast, the MSCI countries have range of volatility between $15 \%$ and $33 \%$. There are 13 emerging countries with volatility higher than $33 \%$ (Argentina, Brazil, Chile, Greece, Indonesia, Mexico, Nigeria, Philippines, Portugal, Taiwan, Turkey, Venezuela, and Zimbabwe).

The autocorrelations are also presented in table 1. In the MSCI sample, there are only five countries with first-order autocorrelation that exceeds $10 \%$. In the emerging countries, there are 12 countries with autocorrelations greater than $10 \%$. Indeed, there are eight countries with autocorrelations above $20 \%$ (Colombia, Indonesia, Mexico, Pakistan, Philippines, Portugal, Turkey, and Venezuela). This suggests that the returns in these countries are predictable based on past information.

The second panel of table 1 examines the most recent subperiod. The same pattern in the summary statistics are evident. For example, one might think that the extraordinary $72 \%$ average return for Argentina might be a function of the a look-back bias because the data begins in 1975.12. However, in the most recent subperiod the average return in Argentina is $88 \%$ ! Indeed, in the most recent subperiod, there are 10 countries whose returns exceed $33 \%$. The predictability is also retained with 10 countries exhibiting serial correlation above $20 \%$.

For comparison purposes, the statistics on the returns in local currency terms are also presented. The wild inflation in Argentina and Brazil is evident in the $228 \%$ and $156 \%$ average returns over the full sample. Other countries that have experienced severe inflation such as Colombia, Chile and Venezuela also have much higher local returns. Calculating the returns in U.S. dollars eliminates the local inflation. However, the U.S. inflation remains in the returns.

The cross-correlations of the emerging markets and the correlations of the emerging markets and the MSCI markets are presented in table 2. Panel A details 
the U.S. dollar return correlations within the emerging markets. These correlations are remarkably small. For example, the correlation between Argentina and Brazil is only $-3 \%$. The correlation between Pakistan and India is $-10 \%$. The correlation between Colombia and Chile is $0 \%$. The correlations in the most recent subperiod (panel B) show the same characteristics. The correlation between Argentina and Brazil is still $-4 \%$.

Panels $\mathrm{C}$ and $\mathrm{D}$ present the correlations in local currency terms. Interestingly, the correlations do not change that much. For example, the correlation between the Argentina and Brazil returns increases to $15 \%$ when measured in local currency terms. Over the shorter sample, the correlation is $16 \%$. The correlation between Colombia and Chile is $-6 \%$.

The correlation between the emerging and developed markets is presented in the next four panels. The average correlations are very small. Malaysia has the highest correlation with developed markets and Mexico has the second highest. For the other countries, the correlations are often less than 10\%. For example, Argentina has correlations less than $10 \%$ for 18 of the 21 developed markets. Korea has correlations less than $10 \%$ for 8 of the 21 developed markets.

The same holds true in the most recent subperiod. Argentina and Venezuela's correlations with each 21 MSCI markets are less than 10\%. There are many countries that have negative correlations with a number developed markets.

Mullin (1993) argues that the low average monthly correlations could be due market imperfections such as lead and lag effects. Mullin shows that the annual correlations are higher than the month correlations. However, it is not clear that they are statistically higher. In my sample (excluding Indonesia), there are 171 cross-correlation coefficients for 19 returns. Using monthly data, 26 are significantly different from zero. With the annual data, only 5 are significantly different from zero. This evidence supports the position that the low correlations are real rather than an artifact of infrequent trading. ${ }^{4}$

4 Using monthly data, there are 5 emerging countries that have significant correlation with the U.S. return. With annual data, only one country has significant correlation (at the $5 \%$ level of significance). However, these are univariate tests 
The low correlations imply significant benefits are possible in diversifying into the emerging markets. Even though the volatility of the individual emerging markets is high, the low correlations should reduce portfolio volatility. This is evident in the work of Divecha, Drach and Stefek (1992), Stone (1990) and Wilcox (1992). Next, I will assess how these benefits translate into portfolio performance.

\section{Asset Allocation}

\subsection{Performance of unconditional asset allocation strategies}

The unconditional minimum-variance frontiers for each month between 1980.12 and 1992.06 are graphed in figure 1. The first panel presents frontiers based on the MSCI sample of developed equity markets. The second panel introduces the emerging markets into the optimization. Overlaying these two panels, it is evident that the introduction of the emerging markets greatly increases the investment possibilities. The frontiers move up (higher mean) and shift inward (lower standard deviation). This is evident even if the emerging markets are restricted to $20 \%$ of the investment portfolio (in panel C).

Figure 2 presents the weights placed on the aggregate of the MSCI portfolios and the emerging portfolios for the two investment strategies. In the first panel, the weights for the minimum-variance strategy is shown. Through the entire sample, the weight on the developed markets decreases and the weight on the emerging markets increases. By the end of the sample, the optimizer wants to place over $90 \%$ of investment funds in emerging markets. The second panel shows the weights of the minimum-variance strategy when the investment in emerging markets is constrained to be at $20 \%$ or below. This constraint is binding in every month.

The next two panels show the weights for the $16 \%$ target volatility strategy. The weights are much more variable in this exercise. Indeed, the weight on the developed markets plunges from above $80 \%$ at the beginning of 1985 to zero for

of correlation. Multivariate tests could be more powerful. 
five months. Other than this one extreme swing, the same pattern persists: If the optimizer is unconstrained, it will place increasing weight on the emerging equities. The constrained optimization with the $20 \%$ cap, shown in the final panel, suggests that the constraint is binding after 1987.

Table 3 presents the performance measures for each of the strategies. First, consider the minimum-variance strategy. When restricted to just developed markets, the out-of-sample performance amounts to $16.09 \%$ per year with a $15.39 \%$ standard deviation. ${ }^{5}$ If emerging markets are added to the problem, the performance increases slightly to $16.35 \%$. More dramatically, the volatility drops to only $11.63 \%$. When the emerging markets are capped at $20 \%$, the actual return increases to $17.02 \%$ and the volatility increases to $14.02 \%$ - however, this is still almost a full percent lower than the strategy that restricts investment to only developed countries. The Sharpe ratios (return in excess of the eurodollar rate ${ }^{6}$ divided by standard deviation) for the three minimum-variance investment strategies are: $0.48,0.66$ and 0.59 . These results suggest an unambiguous benefit to diversifying into emerging markets. Interestingly, the benefit is mainly driven by lower portfolio volatility rather than higher returns.

The first three columns of table 4 detail the year-by-year performance of these strategies. The developed plus emerging markets with the $20 \%$ cap produces returns that are almost always better than the developed countries alone. The exception are the first 6 months of 1992.

The second panel of table 3 shows the results of the $16 \%$ target volatility strategy. All of the strategies have lower returns than the minimum-variance strategies. The highest return, $13.48 \%$, is found in the developed and emerging sample. The Sharpe ratios for the three strategies are $0.23,0.24$ and 0.16 .

The year-by-year performance is presented in the fourth through sixth columns of table 4 . The $16 \%$ target strategy sustains serious losses in 1982,1984

5 For comparison over the same period, the MSCI world return was $14.32 \%$ with a standard deviation of $15.45 \%$. The MSCI U.S. return was $14.96 \%$ with a standard deviation of $15.92 \%$.

6 Based on the average 30-day eurodeposit rate over the 1980.12 to 1992.06 period of $8.7 \%$. 
and 1990. An examination of the returns of the different $16 \%$ volatility strategies does not suggest that any one dominates the others.

Why doesn't the $16 \%$ target strategy perform better than the minimumvariance strategy? The answer has to do with the mean. In solving for the minimum-variance portfolio, you do not need the mean [see Roll (1977, eq. A.14)]. That is, the allocation is not affected by mismeasurement of the mean. However, the $16 \%$ target strategy needs an estimate of the mean. As a result, if the forecast of the return is poor, the $16 \%$ strategy will suffer. The minimum-variance strategy will be relatively immune to a misspecification of the mean. It now makes sense to examine the specification of the mean.

\subsection{Predictability of returns}

A number of world and local information variables are used to forecast the returns on the 41 equity markets. Each variable is known at time $t-1$ when the forecast takes place. The world variables include a constant, the lagged world return, the lagged return on a 10 country currency index ${ }^{7}$, the lagged MSCI world dividend yield, the lagged MSCI earnings-price ratio, and the lagged Eurodollar rate. The local information variables include the lagged country equity return in local currency terms, the lagged change in the country's foreign exchange rate per U.S. dollar, the lagged country dividend and the lagged country's earnings-price ratio. For the emerging countries, the last two information variables are only available beginning in 1985. As a result, these two variables do not enter the regression forecasts until 1985.

The results of the in-sample U.S. dollar regressions are presented in table 5. In the overall sample, 14 of the 21 developed countries exhibit significant predictability. In 9 of these countries, the local information variables help predict the equity returns. A multivariate test of the predictability suggests that we can reject the hypothesis that the expected returns are constant at the $99 \%$ level of confidence.

\footnotetext{
7 See Harvey (1993b) for details on the construction of this index.
} 
The predictability of the emerging returns is detailed in the next panel. The regressions are significant in 12 of the 20 emerging markets. In addition, local information (lagged return, lagged FX) is important in 5 of these countries. There are 9 emerging markets whose $R^{2}$ s exceed $10 \%$. This contrasts to only 4 developed markets with $R^{2}$ above $10 \%$. The multivariate test of predictability provides a strong rejection ( $99.9 \%$ level of confidence) of the hypothesis that the expected emerging returns are constant.

The next panel examines the most recent sample. In the developed countries, returns are predictable in 15 of the 21 countries. For the emerging markets, 13 of 20 regressions are significant. Local information is important in five developed countries. The local information (which now also includes a lagged dividend yield and a lagged earnings-price ratio) is important in 9 of the 20 emerging market regressions. In 18 of the regressions, the $R^{2} \mathrm{~s}$ exceed $10 \%$. Indeed, in 11 of the regressions the $R^{2}$ s exceed $20 \%$. The message from the table is that the emerging returns are predictable - and more predictable than the developed country returns. 


\subsection{The performance of conditional asset allocation strategies}

Figure 3 draws the conditional mean-variance frontiers from 1980.12 to 1992.06 . These frontiers are based on the in-sample expected returns from the regression model (4). For the countries with all the conditioning variables, the full-period coefficient estimates are used for the expected returns. For the countries which are missing the dividend yield and earnings-price ratios before 1985, two models are estimated. The first model omits the dividend yield and earnings-price ratio and fitted values are obtained through 1984.12. The second model uses the most recent data and the full set of conditioning variables and the fitted values are obtained from 1985.01 through 1992.06.

All panels of figure 3 dramatically contrast with figure 1 . The mean-variance frontiers shift across to a lower volatility range and upward to a higher expected return range. In almost every case, the parabola opens up indicating a wider range of investment opportunities. The frontiers are truncated between the annualized expected returns of $-30 \%$ and $70 \%$.

Comparing panels A (developed markets) and panels B (developed and emerging) for the 1981-1985 period, the shape of the frontiers looks similar. However, the frontiers have been shifted to the lower volatility range in panel $\mathrm{B}$. The more dramatic differences appear in the 1986-1992 graphs. When emerging markets are added to the mean-variance problem, the frontier flattens out and moves to the lower standard deviation range. Even when the $20 \%$ cap on the emerging markets is binding (in panel $\mathrm{C}$ ), this flattening out is evident.

Figure 4 plots the investment weights for the minimum volatility and the $16 \%$ target volatility strategies. Similar to figure 2 , when there is no constraint on the weight of the emerging markets in the portfolio, the investment weight assigned to emerging markets increases through time. By 1992, the optimizer tells us to invest only $10 \%$ of our portfolio in developed country stocks. When the problem is rerun with the $20 \%$ cap on emerging markets, the constraint is binding from 1981.

The weights depicted in figure 4 for the $16 \%$ target volatility strategy are 
more variable but follow similar patterns to the ones experienced in figure 2 . There is a huge reweighting to emerging markets beginning in 1986. Over time, when the participation in emerging markets is not constrained, the investment weights increase in these markets. By the last optimization, all investment is placed in emerging markets. The move to emerging markets is also evident in the constrained optimization. By 1986 , the $20 \%$ cap is always binding.

Table 6 presents the returns of the portfolio strategies. The mean (annualized) return when only developed markets are included is $16.99 \%$ with a volatility of 15.14\%. Similar to the unconditional strategy, when emerging markets are added to the problem, the mean return increases to $17.97 \%$ and the volatility plunges to $11.66 \%$. Also similar to the unconditional strategy, when the emerging markets are capped at $20 \%$ the returns increase to $18.87 \%$ and the volatility increases to $14.05 \%$ - still more than a full percentage below the case where we are restricted to only developed markets' equities. The Sharpe ratios for the three strategies are: $0.55,0.80$ and 0.72 .

The conditional minimum volatility (table 6) and the unconditional strategy (table 3 ) have striking similarities. The results are similar because, as mentioned earlier, the minimum-variance portfolio weights do not directly depend on the expected returns vector. The results are not exactly the same for two reasons. First, the problem is different than the one examined in Roll (1977) because of the no short-sales constraint. Second, and more importantly, the mean enters the problem indirectly through the variance-covariance matrix. In the unconditional problem, we use the unconditional variances and covariances. In the conditional problem, we use the average conditional variance and the average conditional covariance. The extent to which the conditional second moment measures differ from their unconditional counterparts will determine the degree of difference in the investment weights.

In the target $16 \%$ volatility strategy, the expected returns play a critical role. In the unconditional strategies in table 3 , the historical average returns were used as the expected returns and the performance of this strategy was inferior to the minimum-variance strategy. For example, in the unconditional minimum- 
variance strategy with developed and capped emerging markets, the average expected volatility was $9.52 \%$ producing a return of $17.02 \%$. In contrast, the unconditional $16 \%$ target volatility (whose average expected volatility was actually $16.19 \%$ ), the return was only $12.09 \%$. By taking on almost double the volatility, your returns go down. This might have seem surprising. However, as noted earlier, the intuition behind this result has to do with the expected returns.

The average historical mean is not a very good forecast of the expected returns in most countries. This is evident from the significant regression results in table 5. In the minimum-volatility strategy, we get around the forecasting problem. However, in the target volatility strategies, you must use have a forecasting model. The results in table 3 suggest that implementing an asset allocation model using historical means as forecasts for the expected returns could have disastrous consequences.

The results in the second panel of table 6 use the regression forecasts for the expected returns. The average expected returns for the developed countries sample is $29.94 \%$ with a volatility of $18.33 \% .^{8}$ When the emerging markets are added to the problem, the returns leap to $54.96 \%$, however the realized volatility jumps to $24.40 \%$. When the emerging markets are constrained to a $20 \%$ portfolio weight, the annual return is $39.30 \%$ with a volatility of $19.89 \% .^{9}$ The Sharpe ratio for strategy with the emerging markets capped at $20 \%$ is 1.53 . This compares to a ratio os 1.16 if the investor is restricted to only developed markets and 0.23 for the strategy that does not use conditioning information.

The year-by-by returns of the six different investments that use conditioning information are presented in table 7 . The minimum-volatility strategy returns are similar to the ones presented in table 4 in that losses are sustained in the first and

8 These results are consistent with Solnik's (1993) study of 8 developed markets over the 1971.01 to 1990.08 period. His unconditional asset allocation produced returns of $18.2 \%$ with a standard deviation of $17.5 \%$. Using the conditional means and the unconditional variances and covariances, the returns increased to $24.6 \%$ and with a volatility of $20.4 \%$.

9 The volatility of the conditional strategy is higher than the target volatility because the average conditional volatility differs from the unconditional volatility by the variance of the conditional means. 
last years. However, the choose $16 \%$ volatility strategies are much different from the unconditional ones presented in table 4 . In the exercise with both developed and capped emerging markets, there is only one year with a small negative return $(1982,-0.49 \%)$. All other years have positive returns and there are five years where the returns exceed $30 \%$.

One potential criticism of the conditional asset allocation exercise is that the regression models are not estimated on an out-of-sample basis. That is, the method assumes fixed coefficients through the entire sample. This could lead to an overfitting problem.

Tables 8 and 9 present the results of a conditional asset allocation exercise where the regression forecasts are calculated on an out-of-sample basis. The conditioning information includes: a constant, lagged world return, lagged change in G-10 exchange rate, lagged world dividend yield, the lagged world earnings-price ratio, the Eurodollar rate, and the lagged country return. For example, the regression model is estimated to 1990:02 (based on information variables available at the end of 1990:01). The estimated coefficients are applied to the information available at the end of 1990:02 to form an out-of-sample forecast for 1990:03. This out-of-sample forecast is the conditional mean for the asset allocation program input.

The results are surprisingly resiliant to the out-of-sample forecasts. For the minimum variance strategy, there is little change which is consistent with the intuition that the conditional mean does not have much of an impact. In the strategy with developed and emerging countries (20\% cap), the average realized return reported in table 8 is $18.28 \%$ with a $14.12 \%$ volatility. This compares to an $18.87 \%$ return using the in-sample forecasts. When the rolling unconditional means are used, the average performance is $17.02 \%$. All of these three sets of conditioning information produce about the same realized volatility.

The performance of the choose $16 \%$ volatility strategy is more affected by the choice of the out-of-sample forecasts. With developed markets only the average return performance is $16.56 \%$ with a volatility of $18.64 \%$ (Sharpe measure of 0.42). In contrast, the unconditional strategy in table 3 reported $13.19 \%$ return 
and $19.55 \%$ standard deviation (Sharpe measure of 0.23 ).

With both developed and emerging markets and using the out-of-sample forecasts, the strategy produces average returns of $25.43 \%$ and a volatility of $19.23 \%$. In contrast, the unconditional results in table 3 showed a $13.48 \%$ return and a $19.92 \%$ standard deviation. The Sharpe measure for the out-of-sample conditional asset allocation is 0.87 compared to 0.24 for the unconditional strategy.

When the out-of-sample forecasts are used with developed and emerging countries ( $20 \%$ cap), the results in table 8 show a $20.25 \%$ return and $19.20 \%$ standard deviation (Sharpe measure of 0.60 ). This is a great improvement over the unconditional strategy which produced a Sharpe measure of only 0.16.

It is not surprising that the returns of the conditional strategies using outof-sample regression forecasts are lower than the conditional strategies using insample regression forecasts. However, the important message is that even using the out-of-sample strategies, the performance of the conditional asset allocation strategies is impressive compared to the unconditional strategies.

The returns implied by the conditional asset allocation suggests that the main benefit of investment in emerging markets comes from the predictability of the emerging market returns. This predictability, combined with the low correlations within emerging markets and with developed markets, enhances portfolio performance. ${ }^{10}$

\section{Conclusions}

The idea of this study is to examine the impact of emerging equity markets on global investment strategies. Recently a number of researchers have documented

10 Implicit in the mean-variance analysis are the assumptions that investors prefer higher expected returns and that the risk (which investors dislike) of the portfolio is captured by the overall variance. It is useful to characterize the risk of the individual markets. Indeed, in implementing portfolio optimization, it is commonplace to add constraints to limit exposure to certain types of risk. Harvey $(1993 \mathrm{a}, \mathrm{c})$ provides some insights on the exposure of the emerging markets to different global risk factors. 
the low correlations between emerging equity returns and developed market returns. In an active portfolio strategy, this means that the opportunity set has become larger: higher expected returns can be gained at lower volatility.

Portfolio simulations were presented to verify that the low correlations produced superior out-of-sample portfolio allocations. The out-of-sample allocation is important because portfolio programs usually produce weights that are ex post optimal. There is no guarantee that these weights will work with data outside the program (in the future). However, strategies that included emerging equity markets consistently outperformed strategies that were limited to developed markets.

While the low correlations with developed markets are important, the most striking advantage of investing in emerging markets relates to their predictability. Regression models were presented that show that the returns in a number of the emerging markets are predictable based on both global and country-specific information variables. When these regression forecasts are combined with a portfolio optimizer, the simulated portfolio performances sharply improve.

One important issue that this paper does not address is the sources of the predictability in the emerging market returns. Indeed a broader issue is the extent to which these markets are integrated into world capital markets. Models that allow for time-varying conditional integration of world capital markets are explored in Bekaert and Harvey (1993).

On a more practical side, as long as the emerging market is investable, the portfolio manager may not care whether the market is integrated. Lack of integration can present opportunities for investors. High expected returns assets can be purchased at prices cheaper than comparable assets in developed countries. The evidence in this paper suggests that there is a benefit to including emerging market assets in a globally diversified portfolio. 


\section{References}

Adler, Michael and Bernard Dumas, 1983, International portfolio selection and corporation finance: A synthesis, Journal of Finance 38, 925-984.

Bailey, Warren and Julapa Jagtiani, 1992, Time-varying premiums for international investment: Some empirical evidence, Working paper, Cornell University, Ithaca, NY.

Bekaert, Geert and Campbell R. Harvey, 1993, Time-varying world market integration, Working paper, Duke University, Durham, NC.

Bekaert, Geert and Robert Hodrick, 1992, Characterizing predictable components in excess returns on equity and foreign exchange markets, Journal of Finance 47, 467-509.

Black, Fischer, 1972, Capital market equilibrium with restricted borrowing, Journal of Finance 45, 444-455.

Campbell, John Y. and Yasushi Hamao, 1992, Predictable bond and stock returns in the United States and Japan: A study of long-term capital market integration, Journal of Finance 47, 43-70.

Chen, Nai-fu, Richard R. Roll, and Stephen A. Roll, 1986, Economic forces and the stock market, Journal of Business 59, 383-403.

Cumby, Robert E. and Jack D. Glen, 1990, Evaluating the performance of international mutual funds, Journal of Finance 45, 497-521.

Divecha, Arjun, Jaime Drach and Dan Stefek, 1992, Emerging markets: A quantitative perspective, Journal of Portfolio Management 19, 41-56.

Dumas, Bernard and Bruno Solnik, 1993, The world price of exchange rate risk, Working paper, Group HEC.

Fama, Eugene F. and Kenneth R. French, 1988, Dividend yields and expected stock returns, Journal of Financial Economics 22, 3-26.

Fama, Eugene F. and Kenneth R. French, 1989, Business conditions and expected returns on stocks and bonds, Journal of Financial Economics 25, 23-50.

Ferson, Wayne E. and Campbell R. Harvey, 1991, The variation of economic risk premiums, Journal of Political Economy 99, 285-315.

Ferson, Wayne E. and Campbell R. Harvey, 1993a, The risk and predictability of international equity returns, Review of Financial Studies, forthcoming.

Ferson, Wayne E. and Campbell R. Harvey, 1993b, Fundamental determinants of national equity market returns, Working paper, Duke University, Durham, NC.

Ferson, Wayne E. and Campbell R. Harvey, 1994, Sources of risk and expected returns in global equity markets, Journal of Banking and Finance, forthcoming.

Gibbons, Michael R. and Wayne E. Ferson, 1985, Tests of asset pricing models with changing expectations and an unobservable market portfolio, Journal of Financial Economics 14, 217-236.

Hansen, Lars P. and Robert J. Hodrick, 1983, Risk averse speculation in the forward foreign exchange market: An econometric analysis of linear models, in Jacob A. 
Frenkel, ed., Exchange rates and international macroeconomics (University of Chicago Press, Chicago, IL).

Harvey, Campbell R., 1989, Time-varying conditional covariances in tests of asset pricing models, Journal of Financial Economics 24, 289-317.

Harvey, Campbell R., 1991, The world price of covariance risk, Journal of Finance 46, 111-157.

Harvey, Campbell R., 1992, The specification of conditional expectations, Working paper, Duke University.

Harvey, Campbell R., 1993a, Predictable risk and returns in emerging markets, Working paper, Duke University, Durham, NC.

Harvey, Campbell R., 1993b, Global risk exposure to a trade-weighted foreign currency index, Working paper, Duke University, Durham, NC.

Harvey, Campbell R., 1993c, Portfolio enhancement using emerging markets and conditioning information, in S. Claessens and S. Gooptu, Eds., Portfolio Investment in Developing Countries World Bank Discussion Paper.

Harvey, Campbell R., Bruno H. Solnik and Guofu Zhou, 1993, What determines expected international asset returns?, Working paper, Duke University, Durham, NC.

Harvey, Campbell R. and Guofu Zhou, 1993, International asset pricing with alternative distributional assumptions, Journal of Empirical Finance 1, 107-131.

Keim, Donald B. and Robert F. Stambaugh, 1986, Predicting returns in the bond and stock market, Journal of Financial Economics 17, 357-390.

Lintner, John, 1965, The valuation of risk assets and the selection of risky investments in stock portfolios and capital budgets, Review of Economics and Statistics 47, 13-37.

Merton, Robert C., 1973, An intertemporal capital asset pricing model, Econometrica $41,867-887$.

Mullin, John, 1993, Emerging equity markets in the global economy, Federal Reserve Bank of New York Quarterly Review 18, 54-83.

Roll, Richard, 1977, A critique of the asset pricing theory's tests, Journal of Financial Economics 4, 129-176.

Roll, Richard, 1992, Industrial structure and the comparative behavior of international stock market indexes, Journal of Finance 47, 3-42.

Roll, Richard and Stephen A. Ross, 1993, On the cross-sectional relation between expected returns and betas, Working paper, UCLA.

Ross, Stephen A., 1976, The arbitrage theory of capital asset pricing, Journal of Economic Theory 13, 341-360.

Ross, Stephen A., 1977, The Capital Asset Pricing Model (CAPM), short sale restrictions and related issues, Journal of Finance 32, 177-183.

Sercu, P., 1980, A generalization of the international asset pricing model, Finance, 91-135.

Sharpe, William, 1964, Capital asset prices: A theory of market equilibrium under conditions of risk, Journal of Finance 19, 425-442. 
Solnik, Bruno, 1974, An equilibrium model of the international capital market, Journal of Economic Theory 8, 500-524.

Solnik, Bruno, 1993, The performance of international asset allocation strategies using conditioning information, Journal of Empirical Finance 1, 33-55.

Stone, Douglas, 1990, The emerging markets and strategic asset allocation, Working paper, Frank Russell Co., Tacoma, WA.

Stulz, René, 1981, A model of international asset pricing, Journal of Financial Economics $9,383-406$.

Wilcox, Jarrod W., 1992, Taming frontier markets, Journal of Porfolio Management $19,51-55$. 
</ref_section> 
Table 1

Means, standard deviations and autocorrelations of international equity returns

\begin{tabular}{|c|c|c|c|c|c|c|c|c|c|c|}
\hline \multirow[b]{2}{*}{ Country } & \multirow[b]{2}{*}{ Start } & \multirow{2}{*}{$\begin{array}{l}\text { Arith. } \\
\text { mean }\end{array}$} & \multirow{2}{*}{$\begin{array}{l}\text { Geo. } \\
\text { mean }\end{array}$} & \multirow[b]{2}{*}{ Std. dev. } & \multicolumn{6}{|c|}{ Autocorrelation } \\
\hline & & & & & $\rho_{1}$ & $\rho_{2}$ & $\rho_{3}$ & $\rho_{4}$ & $\rho_{12}$ & $\rho_{24}$ \\
\hline \multicolumn{11}{|c|}{$\begin{array}{l}\text { Morgan Stanley Capital International-Developed } \\
\text { U.S. dollar returns 1976.01-1992.06 }\end{array}$} \\
\hline Australia & 76.01 & 15.95 & 12.17 & 26.34 & 0.02 & -0.13 & -0.04 & 0.03 & -0.10 & 0.01 \\
\hline Austria & 76.01 & 15.20 & 12.31 & 24.21 & 0.14 & 0.02 & 0.03 & 0.10 & 0.01 & 0.06 \\
\hline Belgium & 76.01 & 18.03 & 15.80 & 20.97 & 0.07 & 0.07 & .0 .03 & 0.05 & -0.01 & 0.03 \\
\hline Canada & 76.01 & 12.44 & 10.39 & 19.93 & -0.02 & -0.07 & 0.06 & .0 .02 & -0.11 & 0.08 \\
\hline Denmark & 76.01 & 14.98 & 13.13 & 19.08 & -0.07 & 0.06 & 0.05 & 0.07 & -0.18 & 0.07 \\
\hline Finland & 88.01 & -9.66 & -12.17 & 22.15 & 0.09 & -0.33 & -0.07 & -0.00 & 0.03 & 0.42 \\
\hline France & 76.01 & 17.78 & 14.51 & 25.26 & 0.02 & -0.02 & 0.10 & 0.06 & -0.10 & 0.01 \\
\hline Germany & 76.01 & 15.17 & 12.73 & 21.81 & -0.04 & -0.01 & 0.12 & 0.10 & -0.08 & 0.00 \\
\hline Hong Kong & 76.01 & 25.45 & 19.25 & 33.88 & 0.02 & -0.05 & -0.05 & -0.12 & -0.06 & -0.00 \\
\hline Ireland & 88.01 & 12.61 & 9.72 & 24.28 & -0.19 & -0.11 & -0.12 & 0.18 & -0.25 & 0.64 \\
\hline Italy & 76.01 & 14.68 & 11.11 & 26.84 & 0.18 & -0.03 & 0.08 & 0.07 & 0.07 & 0.03 \\
\hline Japan & 76.01 & 17.97 & 15.20 & 23.38 & 0.01 & -0.03 & 0.04 & 0.08 & 0.12 & 0.07 \\
\hline Netherlands & 76.01 & 18.95 & 17.30 & 17.53 & -0.06 & -0.09 & 0.05 & -0.04 & 0.01 & -0.04 \\
\hline New Zealand & 88.01 & -1.98 & -5.18 & 26.12 & -0.04 & -0.09 & -0.07 & -0.14 & -0.10 & 0.05 \\
\hline Norway & 76.01 & 16.60 & 12.49 & 28.41 & 0.12 & -0.04 & 0.09 & -0.04 & -0.02 & -0.02 \\
\hline Singapore/Malaysia & 76.01 & 16.72 & 13.05 & 26.21 & 0.03 & 0.02 & -0.10 & 0.06 & -0.05 & 0.04 \\
\hline Spain & 76.01 & 10.32 & 7.32 & 24.47 & 0.11 & 0.00 & -0.04 & 0.11 & -0.03 & 0.12 \\
\hline Sweden & 76.01 & 18.65 & 15.87 & 23.24 & 0.08 & 0.00 & 0.05 & -0.01 & 0.01 & -0.02 \\
\hline Swritzerland & 76.01 & 14.18 & 12.37 & 18.74 & 0.05 & 0.00 & -0.02 & 0.01 & -0.03 & 0.07 \\
\hline United Kingdom & 76.01 & 19.20 & 16.50 & 22.90 & -0.01 & -0.09 & -0.08 & -0.00 & -0.14 & 0.03 \\
\hline United States & 76.01 & 14.27 & 13.00 & 15.46 & -0.01 & -0.06 & -0.08 & -0.04 & -0.02 & 0.06 \\
\hline
\end{tabular}

International Finance Corporation-Emerging

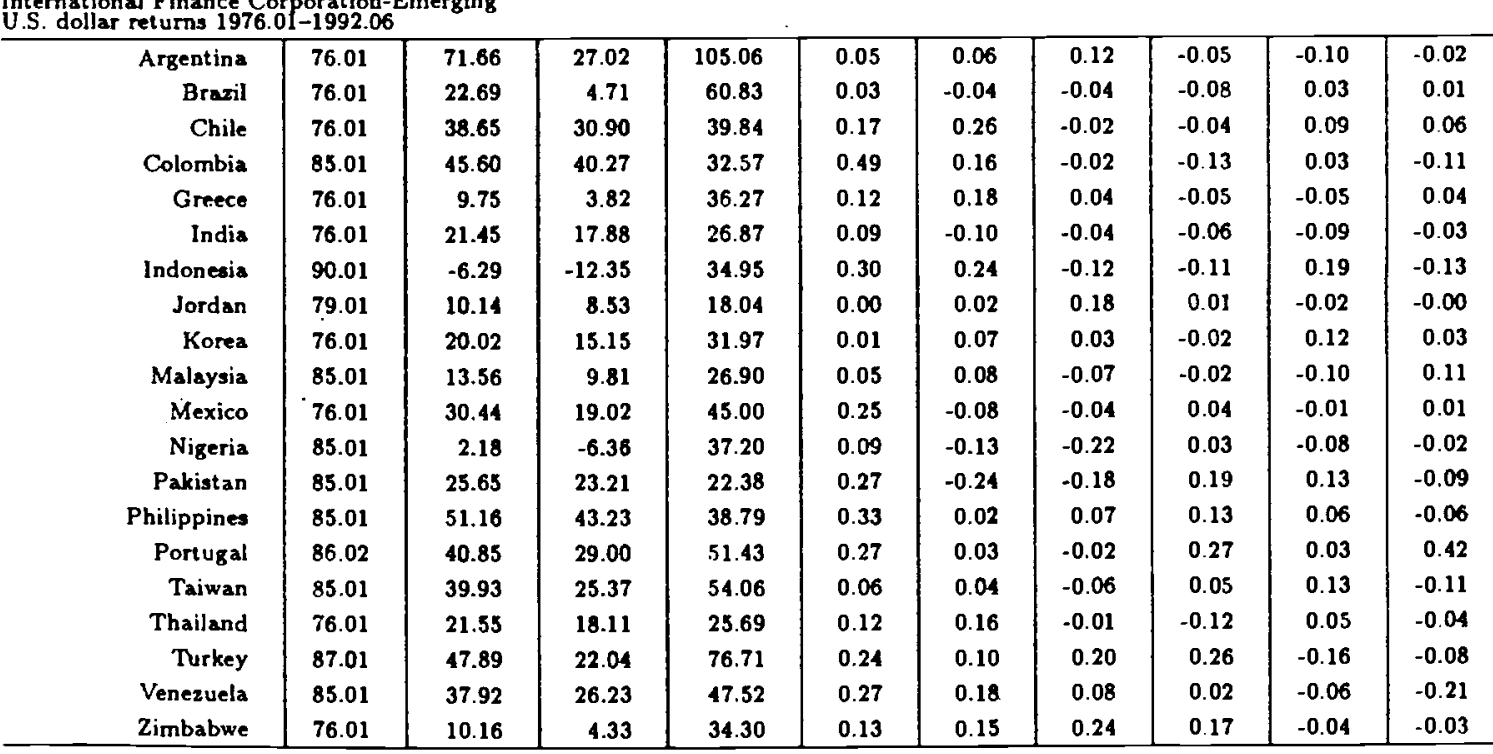


Table 1 (continued)

\begin{tabular}{|c|c|c|c|c|c|c|c|c|c|c|}
\hline \multirow[b]{2}{*}{ Country } & \multirow[b]{2}{*}{ Start } & \multirow{2}{*}{$\begin{array}{l}\text { Arith. } \\
\text { mean }\end{array}$} & \multirow{2}{*}{$\begin{array}{c}\text { Geo. } \\
\text { mean }\end{array}$} & \multirow[b]{2}{*}{ Std. dev. } & \multicolumn{6}{|c|}{ Autocorrelation } \\
\hline & & & & & $\rho_{1}$ & $\rho_{2}$ & $\rho_{3}$ & $\rho_{4}$ & $\rho_{12}$ & $\rho_{24}$ \\
\hline \multicolumn{11}{|c|}{$\begin{array}{l}\text { Morgan Stanley Capital International-Developed } \\
\text { (i.S. dollar returns } 1985.01-1992.06\end{array}$} \\
\hline Australia & 85.01 & 20.94 & 16.23 & 28.48 & -0.04 & -0.06 & -0.06 & -0.06 & -0.17 & 0.02 \\
\hline Austria & 85.01 & 32.75 & 27.53 & 31.93 & 0.14 & -0.05 & -0.03 & 0.12 & -0.03 & 0.02 \\
\hline Belgium & 85.01 & 28.93 & 26.09 & 23.23 & 0.06 & 0.06 & -0.10 & 0.03 & -0.05 & 0.00 \\
\hline Canada & 85.01 & 10.89 & 9.46 & 16.57 & 0.02 & -0.09 & -0.04 & -0.08 & -0.12 & 0.15 \\
\hline Denmark & 85.01 & 22.41 & 19.99 & 21.63 & -0.21 & -0.03 & -0.04 & 0.08 & -0.14 & -0.06 \\
\hline Finland & 88.01 & -9.66 & -12.17 & 22.15 & 0.09 & -0.33 & -0.07 & -0.00 & 0.03 & 0.42 \\
\hline France & 85.01 & 27.66 & 24.30 & 25.16 & 0.00 & -0.01 & 0.13 & 0.10 & -0.13 & 0.03 \\
\hline Germany & 85.01 & 24.17 & 20.60 & 26.13 & -0.02 & -0.01 & 0.11 & 0.15 & -0.10 & -0.04 \\
\hline Hong Kong & 85.01 & 32.36 & 27.11 & 29.58 & -0.08 & -0.11 & -0.00 & -0.12 & -0.12 & -0.02 \\
\hline Ireland & 88.01 & 12.61 & 9.72 & 24.28 & -0.19 & -0.11 & -0.12 & 0.18 & -0.25 & 0.64 \\
\hline Italy & 85.01 & 22.29 & 18.73 & 26.76 & 0.22 & 0.07 & 0.15 & 0.16 & -0.00 & 0.01 \\
\hline Japan & 85.01 & 17.78 & 13.90 & 27.91 & 0.04 & 0.03 & 0.03 & 0.07 & 0.14 & 0.10 \\
\hline Netherlands & 85.01 & 23.07 & 21.52 & 16.47 & -0.06 & -0.09 & 0.11 & 0.00 & 0.04 & 0.12 \\
\hline New Zealand & 88.01 & -1.98 & -5.18 & 26.12 & -0.04 & -0.09 & -0.07 & -0.14 & -0.10 & 0.05 \\
\hline Norway & 85.01 & 19.85 & 15.74 & 28.09 & 0.08 & -0.03 & 0.01 & -0.11 & -0.05 & -0.06 \\
\hline Singapore/Malaysia & 85.01 & 16.31 & 12.08 & 27.52 & 0.03 & 0.03 & -0.13 & 0.13 & -0.14 & 0.14 \\
\hline Spain & 85.01 & 28.17 & 24.38 & 27.00 & 0.14 & -0.09 & -0.11 & 0.04 & -0.08 & 0.08 \\
\hline Sweden & 85.01 & 24.85 & 21.81 & 23.82 & 0.17 & -0.05 & -0.15 & -0.05 & 0.07 & 0.04 \\
\hline Switzerland & 85.01 & 21.74 & 19.46 & 20.81 & 0.05 & -0.00 & -0.04 & 0.04 & -0.06 & 0.07 \\
\hline United Kingdom & 85.01 & 23.13 & 20.23 & 23.48 & -0.10 & -0.14 & -0.04 & 0.04 & -0.11 & 0.05 \\
\hline United States & 85.01 & 16.88 & 15.32 & 16.96 & 0.02 & -0.08 & -0.10 & -0.16 & -0.04 & 0.08 \\
\hline
\end{tabular}

International Finance Corporation-Emerging

\begin{tabular}{|c|c|c|c|c|c|c|c|c|c|c|}
\hline Argentina & 85.01 & 87.65 & 38.13 & 115.85 & -0.03 & -0.00 & 0.12 & -0.17 & -0.08 & 0.10 \\
\hline Brazil & 85.01 & 35.60 & 6.43 & 77.19 & 0.01 & 0.04 & -0.07 & -0.12 & 0.01 & -0.01 \\
\hline Chile & 85.01 & 53.45 & 48.79 & 27.61 & 0.27 & -0.10 & -0.34 & -0.27 & 0.09 & -0.06 \\
\hline Colombia & 85.01 & 45.60 & 40.27 & 32.57 & 0.49 & 0.16 & -0.02 & -0.13 & 0.03 & -0.11 \\
\hline Greece & 85.01 & 37.80 & 27.35 & 47.98 & 0.10 & 0.17 & -0.02 & -0.16 & -0.14 & -0.02 \\
\hline India & 85.01 & 26.92 & 20.85 & 35.29 & 0.15 & -0.11 & -0.08 & .0 .04 & -0.14 & -0.06 \\
\hline Indonesia & 90.01 & -6.29 & -12.35 & 34.95 & 0.30 & 0.24 & -0.12 & -0.11 & 0.19 & -0.13 \\
\hline Jordan & 85.01 & 7.83 & 6.23 & 17.99 & -0.05 & -0.06 & 0.19 & -0.10 & 0.15 & -0.18 \\
\hline Korea & 85.01 & 22.90 & 18.39 & 30.23 & -0.02 & 0.20 & 0.03 & 0.20 & 0.12 & 0.18 \\
\hline Malaysia & 85.01 & 13.56 & 9.81 & 26.90 & 0.05 & 0.08 & -0.07 & -0.02 & -0.10 & 0.11 \\
\hline Mexico & 85.01 & 55.80 & 41.81 & 48.15 & 0.30 & -0.18 & -0.29 & -0.06 & -0.06 & 0.07 \\
\hline Nigeria & 85.01 & 2.18 & -6.36 & 37.20 & 0.09 & -0.13 & -0.22 & 0.03 & -0.08 & -0.02 \\
\hline Pakistan & 85.01 & 25.65 & 23.21 & 22.38 & 0.27 & -0.24 & -0.18 & 0.19 & 0.13 & -0.09 \\
\hline Philippines & 85.01 & 51.16 & 43.23 & 38.79 & 0.33 & 0.02 & 0.07 & 0.13 & 0.06 & -0.06 \\
\hline Portugal & 86.02 & 40.85 & 29.00 & 51.43 & 0.27 & 0.03 & -0.02 & 0.27 & 0.03 & 0.42 \\
\hline Taiwan & B5.01 & 39.93 & 25.37 & 54.06 & 0.06 & 0.04 & -0.06 & 0.05 & 0.13 & -0.11 \\
\hline Thailand & 85.01 & 31.26 & 26.38 & 29.73 & 0.13 & 0.04 & -0.07 & -0.28 & -0.06 & -0.01 \\
\hline Turkey & 87.01 & 47.89 & 22.04 & 76.71 & 0.24 & 0.10 & 0.20 & 0.26 & -0.16 & -0.08 \\
\hline Venezuela & 85.01 & 37.92 & 26.23 & 47.52 & 0.27 & 0.18 & 0.08 & 0.02 & -0.06 & -0.21 \\
\hline Zimbabwe & B5.01 & 28.05 & 22.98 & 32.06 & 0.26 & 0.31 & 0.26 & 0.31 & -0.11 & 0.03 \\
\hline
\end{tabular}


Table 1 (continued)

\begin{tabular}{|c|c|c|c|c|c|c|c|c|c|c|}
\hline \multicolumn{11}{|c|}{$\begin{array}{l}\text { Morgan Stanley Capital International-Developed } \\
\text { Local currency retums 1976.01-1992.06 }\end{array}$} \\
\hline Australia & 76.01 & 18.00 & 15.32 & 21.93 & 0.06 & -0.18 & -0.06 & 0.13 & -0.08 & 0.04 \\
\hline Austria & 76.01 & 11.48 & 9.23 & 21.40 & 0.22 & -0.02 & -0.07 & 0.10 & 0.01 & 0.02 \\
\hline Belgium & 76.01 & 15.98 & 14.29 & 18.11 & 0.20 & -0.02 & -0.15 & -0.06 & 0.03 & -0.09 \\
\hline Canada & 76.01 & 13.03 & 11.38 & 17.78 & -0.00 & -0.05 & 0.06 & -0.01 & -0.07 & 0.09 \\
\hline Denmark & 76.01 & 14.36 & 12.83 & 17.23 & 0.11 & 0.05 & 0.14 & 0.16 & -0.11 & 0.04 \\
\hline Finland & 88.01 & -8.29 & -10.97 & 23.18 & 0.15 & -0.14 & 0.05 & 0.02 & 0.09 & 0.39 \\
\hline France & 76.01 & 17.84 & 15.35 & 21.96 & 0.07 & -0.06 & 0.00 & 0.08 & -0.08 & -0.02 \\
\hline Germany & 76.01 & 10.96 & 9.23 & 18.28 & 0.07 & -0.06 & 0.08 & 0.05 & -0.04 & -0.06 \\
\hline Hong Kong & 76.01 & 27.64 & 21.84 & 32.74 & -0.00 & -0.04 & -0.04 & -0.13 & -0.07 & -0.03 \\
\hline Ireland & 88.01 & 11.52 & 8.67 & 24.11 & 0.04 & -0.13 & -0.10 & 0.27 & -0.15 & 0.43 \\
\hline Italy & 76.01 & 17.58 & 14.29 & 25.80 & 0.15 & -0.01 & 0.08 & 0.05 & 0.07 & 0.04 \\
\hline Japan & 76.01 & 11.49 & 9.85 & 17.96 & -0.01 & 0.07 & -0.02 & 0.01 & 0.06 & 0.10 \\
\hline Netherlands & 76.01 & 16.13 & 14.63 & 16.82 & 0.03 & -0.05 & 0.00 & -0.08 & 0.09 & -0.05 \\
\hline New Zealand & 88.01 & 2.20 & -0.95 & 25.99 & -0.09 & -0.04 & -0.00 & -0.15 & -0.02 & -0.01 \\
\hline Norway & 76.01 & 16,69 & 12.91 & 27.13 & 0.15 & -0.08 & 0.09 & -0.06 & 0.05 & -0.03 \\
\hline Singapore/Malaysis & 76.01 & 13.85 & 10.44 & 25.21 & 0.07 & 0.03 & -0.10 & 0.04 & -0.03 & 0.04 \\
\hline Spain & 76.01 & 12.50 & 10.11 & 21.81 & 0.15 & 0.01 & -0.11 & 0.08 & 0.02 & 0.09 \\
\hline Sweden & 76.01 & 19.86 & 17.23 & 22.50 & 0.21 & 0.05 & 0.04 & 0.05 & 0.07 & 0.02 \\
\hline Switzerland & 76.01 & 9.73 & 8.48 & 15.48 & 0.13 & -0.01 & -0.12 & -0.09 & -0.02 & 0.01 \\
\hline United Kingdom & 76.01 & 18.85 & 16.86 & 19.25 & 0.01 & -0.14 & -0.08 & -0.00 & -0.07 & -0.00 \\
\hline United States & 76.01 & 14.27 & 13.00 & 15.46 & -0.01 & -0.06 & -0.08 & -0.04 & -0.02 & 0.06 \\
\hline
\end{tabular}

International Finance Corporation-Emerging Local currency returns 1976.01-1992.06

\begin{tabular}{|c|c|c|c|c|c|c|c|c|c|c|}
\hline Argentina & 76.01 & 228.93 & 155.60 & 147.94 & 0.18 & 0.20 & 0.12 & -0.01 & .0 .02 & -0.11 \\
\hline Brazil & 76.01 & 155.90 & 124.26 & 79.54 & 0.16 & 0.23 & 0.15 & 0.17 & 0.20 & 0.11 \\
\hline Chile & 76.01 & 61.44 & 53.35 & 39.06 & 0.17 & 0.29 & 0.00 & -0.00 & 0.15 & 0.06 \\
\hline Colombia & 85.01 & 71.92 & 65.55 & 32.52 & 0.48 & 0.14 & -0.04 & -0.16 & 0.04 & -0.15 \\
\hline Greece & 76.01 & 19.24 & 13.82 & 34.76 & 0.11 & 0.15 & 0.01 & -0.10 & -0.06 & 0.02 \\
\hline India & 76.01 & 28.85 & 24.90 & 28.20 & 0.11 & -0.09 & -0.07 & -0.08 & -0.02 & -0.04 \\
\hline Indonesia & 90.01 & -1.36 & -7.44 & 35.15 & 0.29 & 0.24 & -0.12 & -0.10 & 0.20 & -0.14 \\
\hline Jordan & 79.01 & 16.04 & 14.51 & 17.35 & 0.08 & 0.05 & 0.14 & -0.02 & -0.02 & 0.01 \\
\hline Korea & 76.01 & 22.90 & 18.12 & 31.57 & -0.05 & 0.06 & 0.01 & -0.05 & 0.13 & 0.04 \\
\hline Malaysia & 85.01 & 13.91 & 10.23 & 26.53 & 0.06 & 0.07 & -0.10 & -0.02 & -0.06 & 0.12 \\
\hline Mexico & 76.01 & 62.35 & 52.45 & 42.35 & 0.34 & 0.00 & 0.03 & 0.12 & 0.06 & 0.07 \\
\hline Nigeria & 85.01 & 35.93 & 34.76 & 12.03 & 0.11 & -0.04 & -0.01 & 0.11 & 0.10 & -0.14 \\
\hline Pakistan & 85.01 & 32.30 & 29.70 & 22.49 & 0.27 & -0.25 & -0.16 & 0.21 & 0.13 & -0.08 \\
\hline Philippines & 85.01 & 54.61 & 46.26 & 40.40 & 0.28 & -0.03 & 0.03 & 0.15 & 0.04 & -0.09 \\
\hline Portugal & 86.02 & 37.67 & 25.89 & 51.32 & 0.27 & 0.03 & -0.07 & 0.31 & 0.08 & 0.52 \\
\hline Taiwan & 85.01 & 32.82 & 18.94 & 52.80 & 0.05 & 0.03 & .0 .09 & 0.02 & 0.13 & -0.12 \\
\hline Thailand & 76.01 & 22.80 & 19.42 & 25.37 & 0.12 & 0.16 & -0.01 & -0.12 & 0.05 & -0.06 \\
\hline Turkey & 87.01 & 88.53 & 61.93 & 76.89 & 0.18 & 0.08 & 0.13 & 0.22 & -0.15 & -0.07 \\
\hline Venezuela & 85.01 & 63.78 & 55.07 & 40.26 & 0.37 & 0.21 & 0.19 & 0.20 & -0.04 & -0.27 \\
\hline Zimbabwe & 76.01 & 22.15 & 16.71 & 33.04 & 0.10 & 0.13 & 0.25 & 0.21 & -0.05 & -0.02 \\
\hline
\end{tabular}


Table 1 (continued)

\begin{tabular}{|c|c|c|c|c|c|c|c|c|c|c|}
\hline \multirow[b]{2}{*}{ Country } & \multirow[b]{2}{*}{ Start } & \multirow{2}{*}{$\begin{array}{l}\text { Arith. } \\
\text { mean }\end{array}$} & \multirow{2}{*}{$\begin{array}{l}\text { Geo. } \\
\text { mean }\end{array}$} & \multirow[b]{2}{*}{ Std. dev. } & \multicolumn{6}{|c|}{ Autocorrelation } \\
\hline & & & & & $\rho_{1}$ & $\rho_{2}$ & $\rho_{3}$ & $\rho_{4}$ & $\rho_{12}$ & $\rho_{24}$ \\
\hline \multicolumn{11}{|c|}{$\begin{array}{l}\text { Morgan Stanley Capital International-Developed } \\
\text { Local currency returns } 1985.01-1992.06\end{array}$} \\
\hline Australia & 85.01 & 20.74 & 17.56 & 22.93 & -0.02 & -0.05 & -0.08 & 0.03 & -0.09 & 0.14 \\
\hline Austria & 85.01 & 22.56 & 17.93 & 30.55 & 0.21 & -0.05 & -0.11 & 0.08 & -0.02 & -0.04 \\
\hline Belgium & 85.01 & 19.04 & 16.74 & 21.12 & 0.20 & -0.05 & -0.19 & -0.11 & -0.01 & -0.19 \\
\hline Canada & 85.01 & 9.34 & 8.15 & 15.06 & 0.02 & -0.07 & -0.01 & -0.09 & -0.10 & 0.17 \\
\hline Denmark & 85.01 & 13.02 & 11.30 & 18.41 & -0.00 & -0.07 & 0.10 & 0.14 & -0.11 & -0.02 \\
\hline Finland & 88.01 & -8.29 & -10.97 & 23.18 & 0.15 & -0.14 & 0.05 & 0.02 & 0.09 & 0.39 \\
\hline France & 85.01 & 18.68 & 15.92 & 23.12 & 0.13 & -0.03 & 0.12 & 0.05 & -0.11 & -0.08 \\
\hline Germany & 85.01 & 13.87 & 10.96 & 23.70 & 0.09 & -0.06 & 0.06 & 0.05 & -0.05 & -0.20 \\
\hline Hong Kong & 85.01 & 32.80 & 26.96 & 31.45 & -0.13 & -0.10 & -0.01 & -0.12 & -0.10 & -0.01 \\
\hline Ireland & 88.01 & 11.52 & 8.67 & 24.11 & 0.04 & -0.13 & -0.10 & 0.27 & -0.15 & 0.43 \\
\hline Italy & 85.01 & 15.00 & 11.87 & 25.24 & 0.20 & 0.11 & 0.11 & 0.05 & -0.03 & -0.10 \\
\hline Japan & 85.01 & 7.33 & 4.71 & 22.93 & 0.01 & 0.11 & -0.01 & 0.02 & 0.10 & 0.07 \\
\hline Netherlands & 85.01 & 13.38 & 11.86 & 16.87 & 0.14 & -0.06 & 0.01 & -0.19 & 0.08 & -0.09 \\
\hline New Zealand & 88.01 & 2.20 & -0.95 & 25.99 & -0.09 & -0.04 & -0.00 & -0.15 & -0.02 & -0.01 \\
\hline Norway & 85.01 & 14.08 & 10.16 & 27.36 & 0.16 & -0.07 & 0.02 & -0.19 & 0.01 & -0.07 \\
\hline Singapore/Malaysia & 85.01 & 12.25 & 8.11 & 27.22 & 0.09 & 0.04 & -0.10 & 0.11 & -0.09 & 0.14 \\
\hline Spain & 85.01 & 19.88 & 16.55 & 25.51 & 0.24 & -0.08 & -0.20 & -0.01 & -0.05 & 0.09 \\
\hline Sweden & 85.01 & 18.30 & 15.33 & 23.73 & 0.24 & -0.00 & -0.21 & -0.09 & 0.08 & 0.00 \\
\hline Switzerland & 85.01 & 13.14 & 11.04 & 20.09 & 0.13 & -0.00 & -0.13 & -0.13 & -0.07 & -0.14 \\
\hline United Kingdom & 85.01 & 15.81 & 13.66 & 20.06 & -0.01 & -0.19 & -0.01 & 0.03 & -0.07 & -0.06 \\
\hline United States & 85.01 & 16.88 & 15.32 & 16.96 & 0.02 & -0.08 & -0.10 & -0.16 & -0.04 & 0.08 \\
\hline
\end{tabular}

International Finance Corporation-Emerging

Local currency returns 1985.01-1992.06

\begin{tabular}{|c|c|c|c|c|c|c|c|c|c|c|}
\hline Argentina & 85.01 & 286.32 & 183.65 & 187.75 & 0.15 & 0.21 & 0.11 & -0.05 & -0.02 & -0.10 \\
\hline Brazil & 85.01 & 247.09 & 191.35 & 100.36 & 0.03 & 0.21 & 0.04 & 0.06 & 0.12 & 0.00 \\
\hline Chile & 85.01 & 66.94 & 61.99 & 26.49 & 0.29 & -0.08 & -0.31 & -0.27 & 0.09 & -0.06 \\
\hline Colombia & 85.01 & 71.92 & 65.55 & 32.52 & 0.48 & 0.14 & -0.04 & -0.16 & 0.04 & -0.15 \\
\hline Greece & 85.01 & 42.40 & 32.25 & 47.19 & 0.09 & 0.16 & -0.03 & -0.18 & -0.10 & -0.02 \\
\hline India & 85.01 & 38.92 & 31.88 & 37.90 & 0.15 & -0.10 & -0.11 & -0.09 & -0.04 & -0.08 \\
\hline Indonesia & 90.01 & -1.36 & -7.44 & 35.15 & 0.29 & 0.24 & -0.12 & -0.10 & 0.20 & -0.14 \\
\hline Jordan & 85.01 & 14.20 & 12.69 & 17.38 & 0.06 & -0.04 & 0.18 & -0.16 & 0.14 & -0.13 \\
\hline Korea & 85.01 & 22.11 & 17.79 & 29.62 & -0.09 & 0.17 & 0.00 & 0.18 & 0.11 & 0.18 \\
\hline Malaysia & 85.01 & 13.91 & 10.23 & 26.53 & 0.06 & 0.07 & -0.10 & -0.02 & -0.06 & 0.12 \\
\hline Mexico & 85.01 & 93.65 & 78.90 & 49.33 & 0.37 & -0.04 & -0.13 & 0.03 & 0.01 & 0.09 \\
\hline Nigeria & 85.01 & 35.93 & 34.76 & 12.03 & 0.11 & -0.04 & -0.01 & 0.11 & 0.10 & -0.14 \\
\hline Pakistan & 85.01 & 32.30 & 29.70 & 22.49 & 0.27 & -0.25 & -0.16 & 0.21 & 0.13 & -0.08 \\
\hline Philippines & 85.01 & 54.61 & 46.26 & 40.40 & 0.28 & -0.03 & 0.03 & 0.15 & 0.04 & -0.09 \\
\hline Portugal & 86.02 & 37.67 & 25.89 & 51.32 & 0.27 & 0.03 & -0.07 & 0.31 & 0.08 & 0.52 \\
\hline Täiwan & 85.01 & 32.82 & 18.94 & 52.80 & 0.05 & 0.03 & -0.09 & 0.02 & 0.13 & -0.12 \\
\hline Thailand & 85.01 & 30.32 & 25.44 & 29.76 & 0.16 & 0.05 & -0.08 & -0.28 & -0.04 & -0.04 \\
\hline Turkey & 87.01 & 88.53 & 61.93 & 76.89 & 0.18 & 0.08 & 0.13 & 0.22 & -0.15 & -0.07 \\
\hline Venezuela & 85.01 & 63.78 & 55.07 & 40.26 & 0.37 & 0.21 & 0.19 & 0.20 & -0.04 & -0.27 \\
\hline Zimbabwe & 85.01 & 43.35 & 38.52 & 30.26 & 0.26 & 0.19 & 0.33 & 0.32 & -0.08 & -0.08 \\
\hline
\end{tabular}

Note: Table 2 has been omitted. 
Figure 1

Unconditional asset allocation

A. Developed markets: no short sales
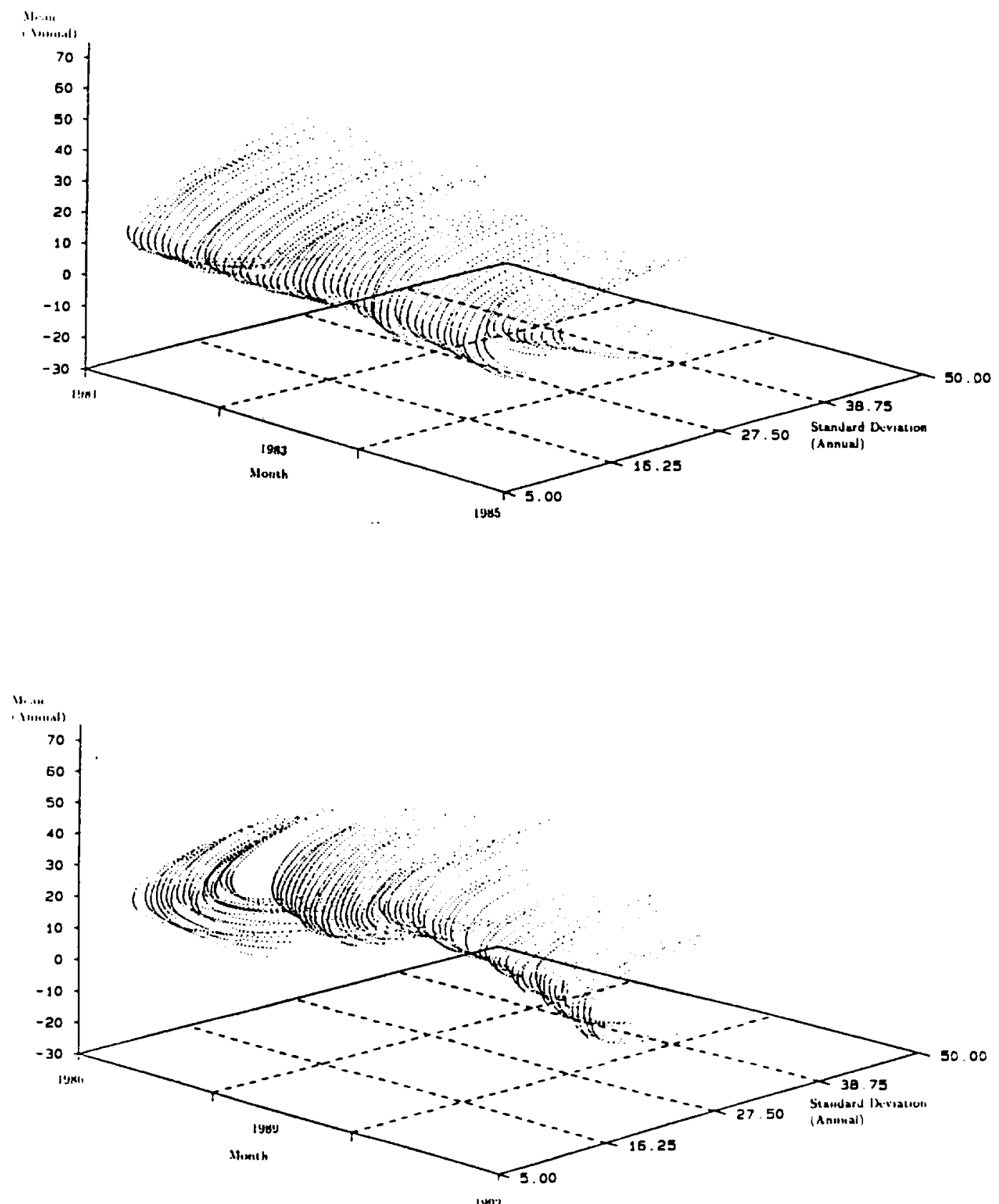
Figure 1 (continued)

B. Developed and emerging markets: no short sales
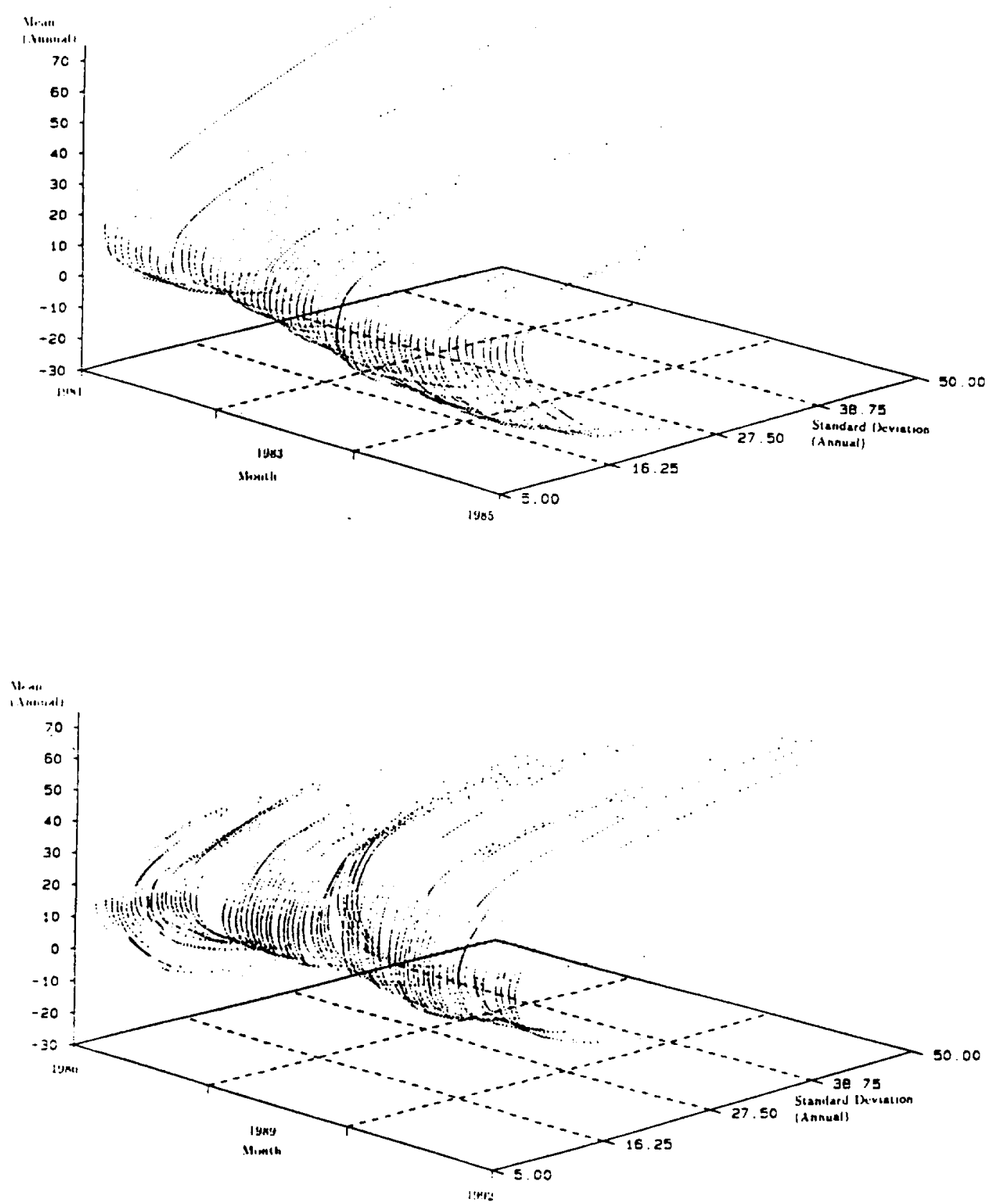
Figure 1 (continued)

C. Developed and cmerging markets (20\% cap): no short sales
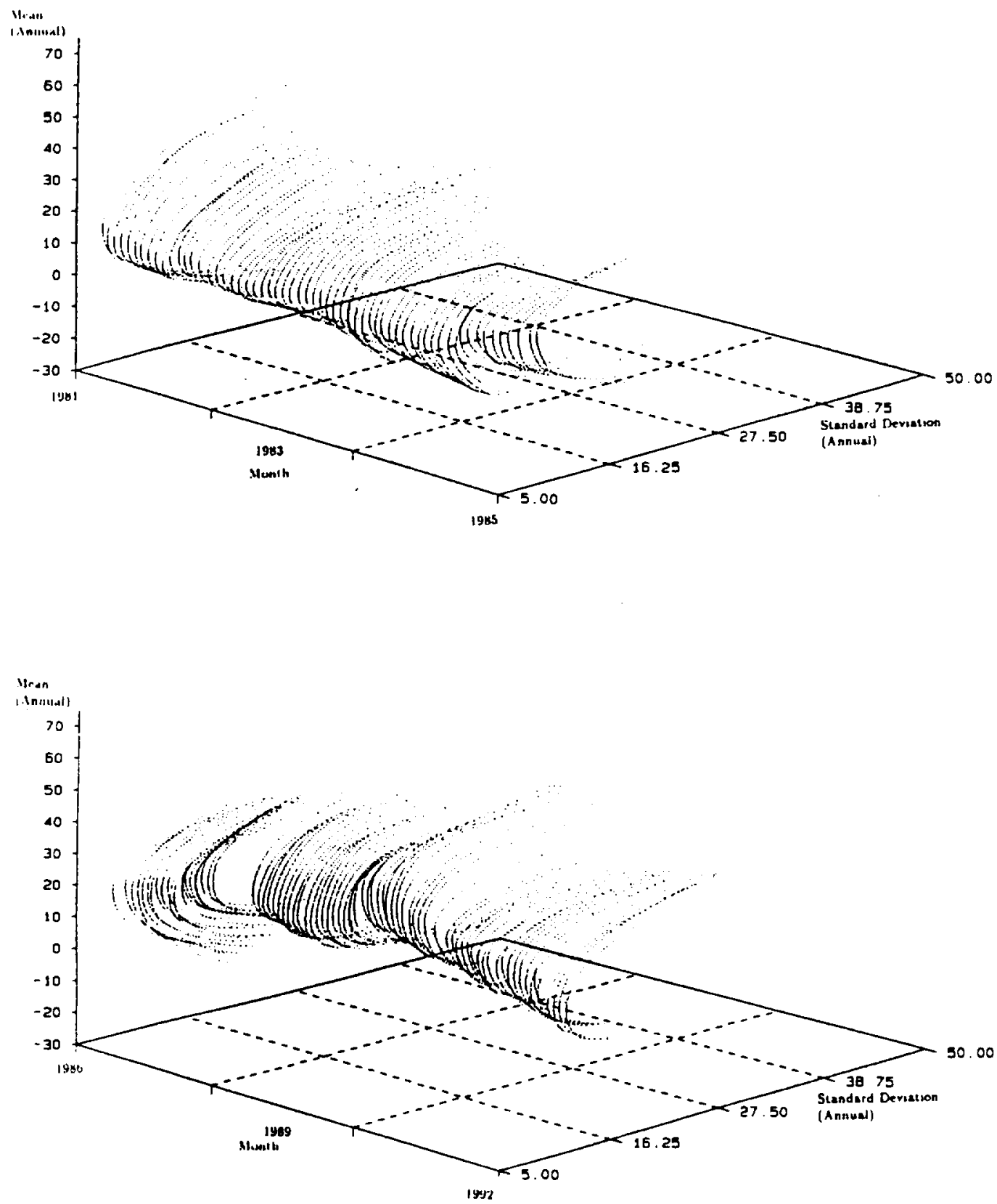
Figure 2

Unconditional allocation investment weights

A. Minimum volatility strategy

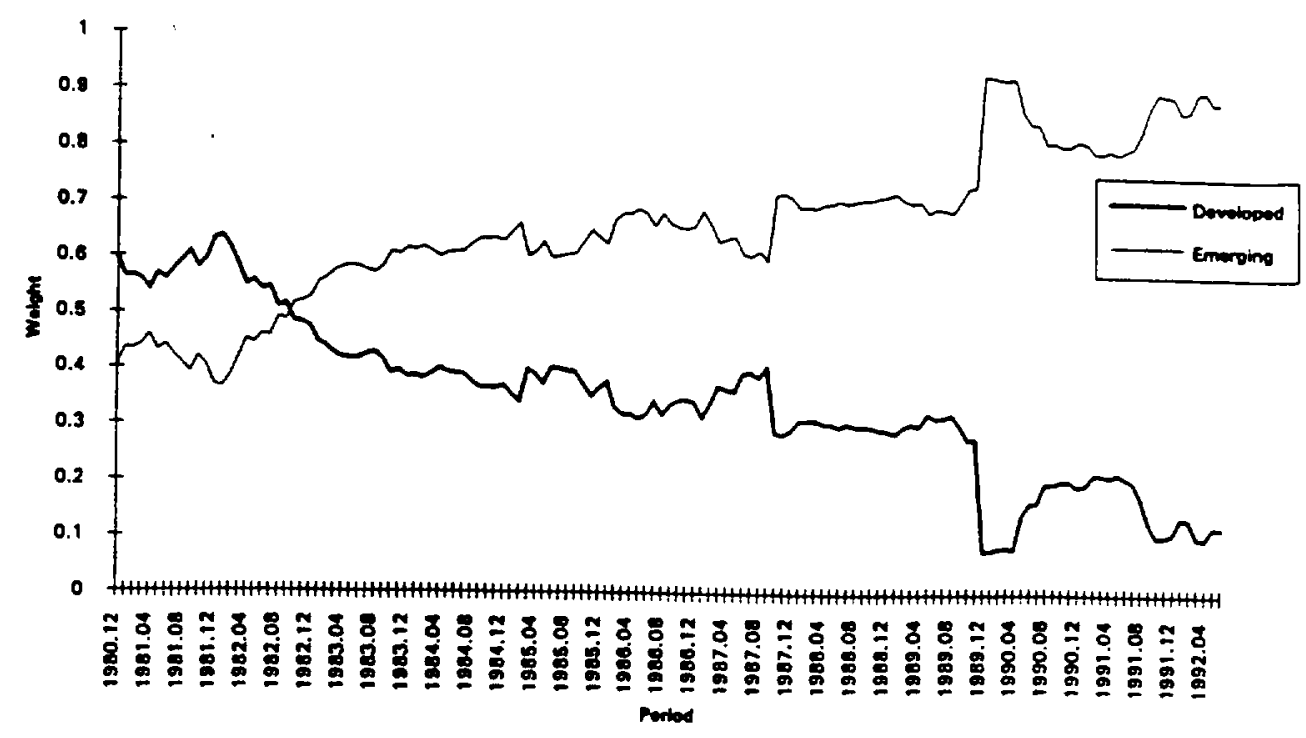

B. Minimum volatility strategy with $20 \%$ emerging cap

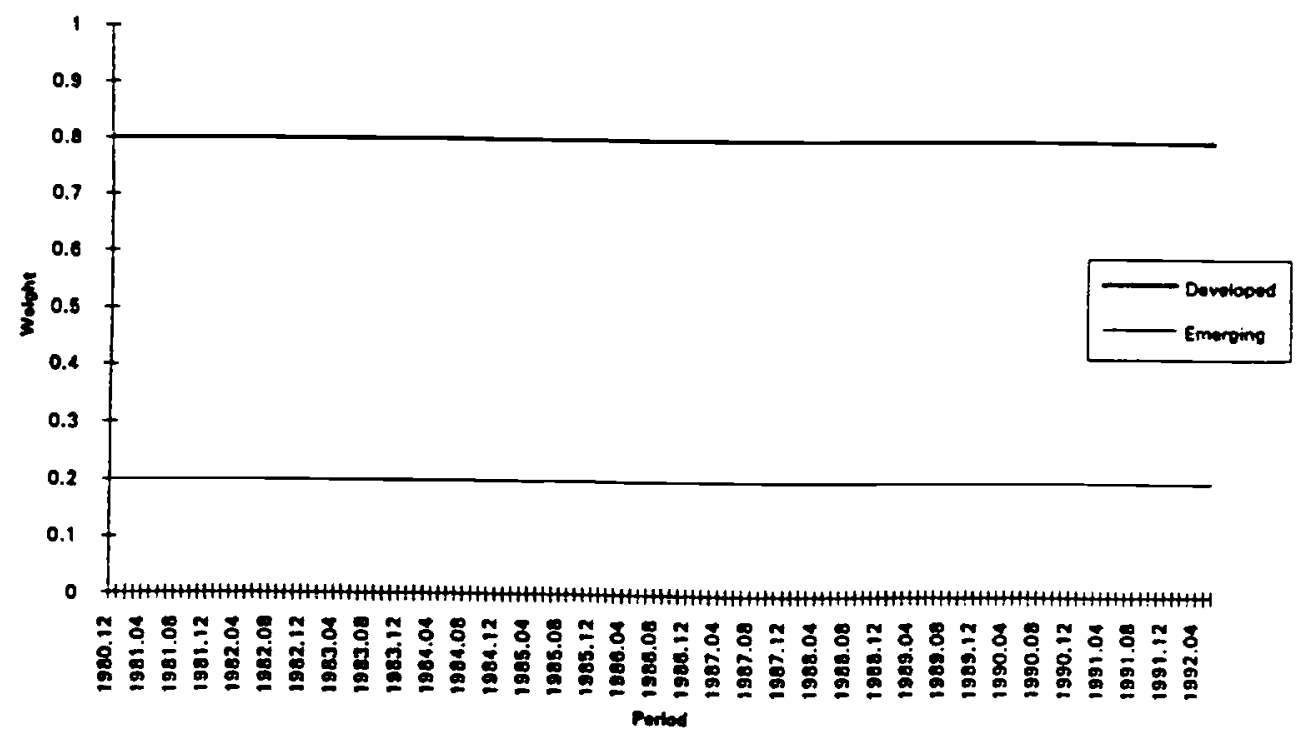


Figure 2 (continued)

C. Target volatility of $16 \%$ strategy

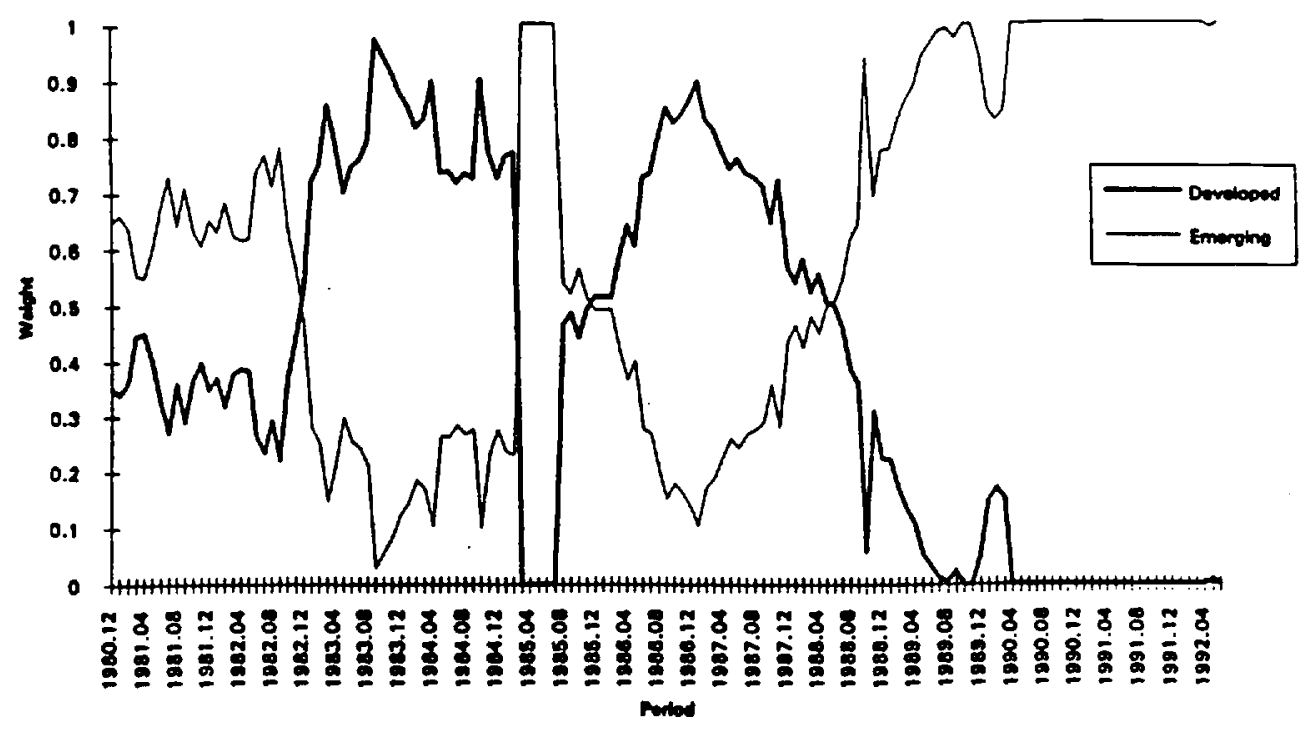

D. Target volatility of $16 \%$ strotegy with $20 \%$ emerging cap

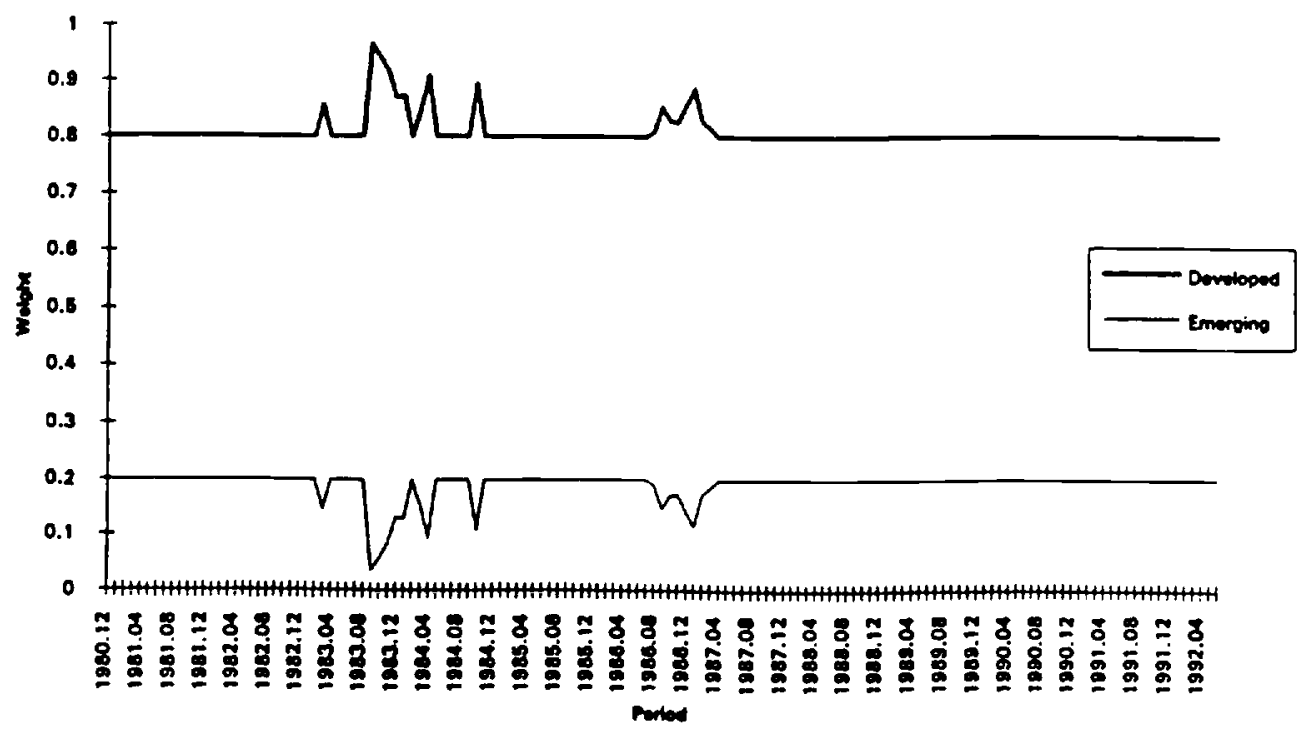


Table 3

Performance of Unconditional Asset Allocation

\begin{tabular}{|c|c|c|c|c|c|c|}
\hline Universe & $\begin{array}{l}\text { Cumulative } \\
\text { return }\end{array}$ & $\begin{array}{c}\text { Mean } \\
\text { return } \\
\text { (annualized) }\end{array}$ & $\begin{array}{c}\text { Standard } \\
\text { deviation } \\
\text { (annualized) }\end{array}$ & $\begin{array}{c}\text { Target } \\
\text { standard } \\
\text { deviation }\end{array}$ & Minimum & Maximum \\
\hline
\end{tabular}

Strategy: Choose minimum variance port folio 1980.01-1992.06

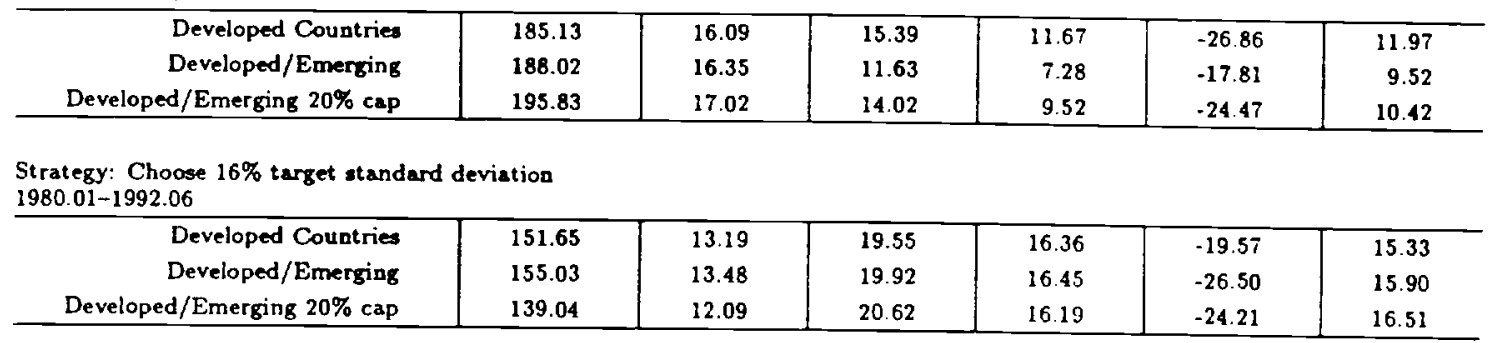


Table 4

Year by Year Performance of Unconditional Asset Allocation

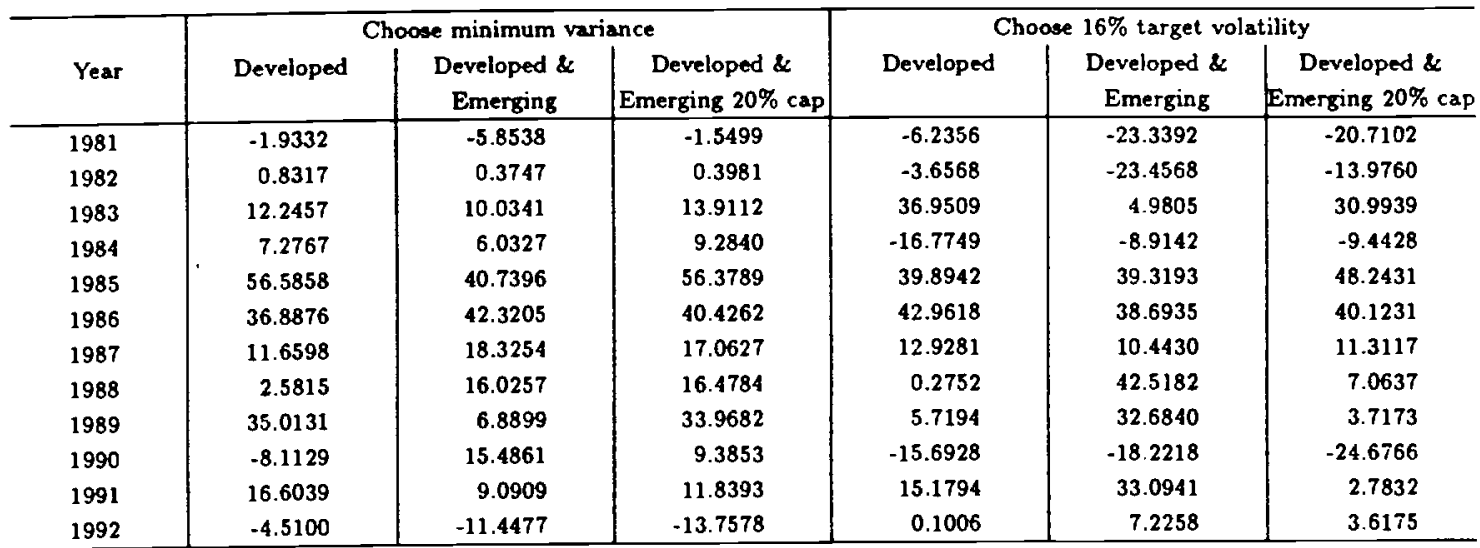


Table 5

The Predictability of Equity Returns in 41 Markets

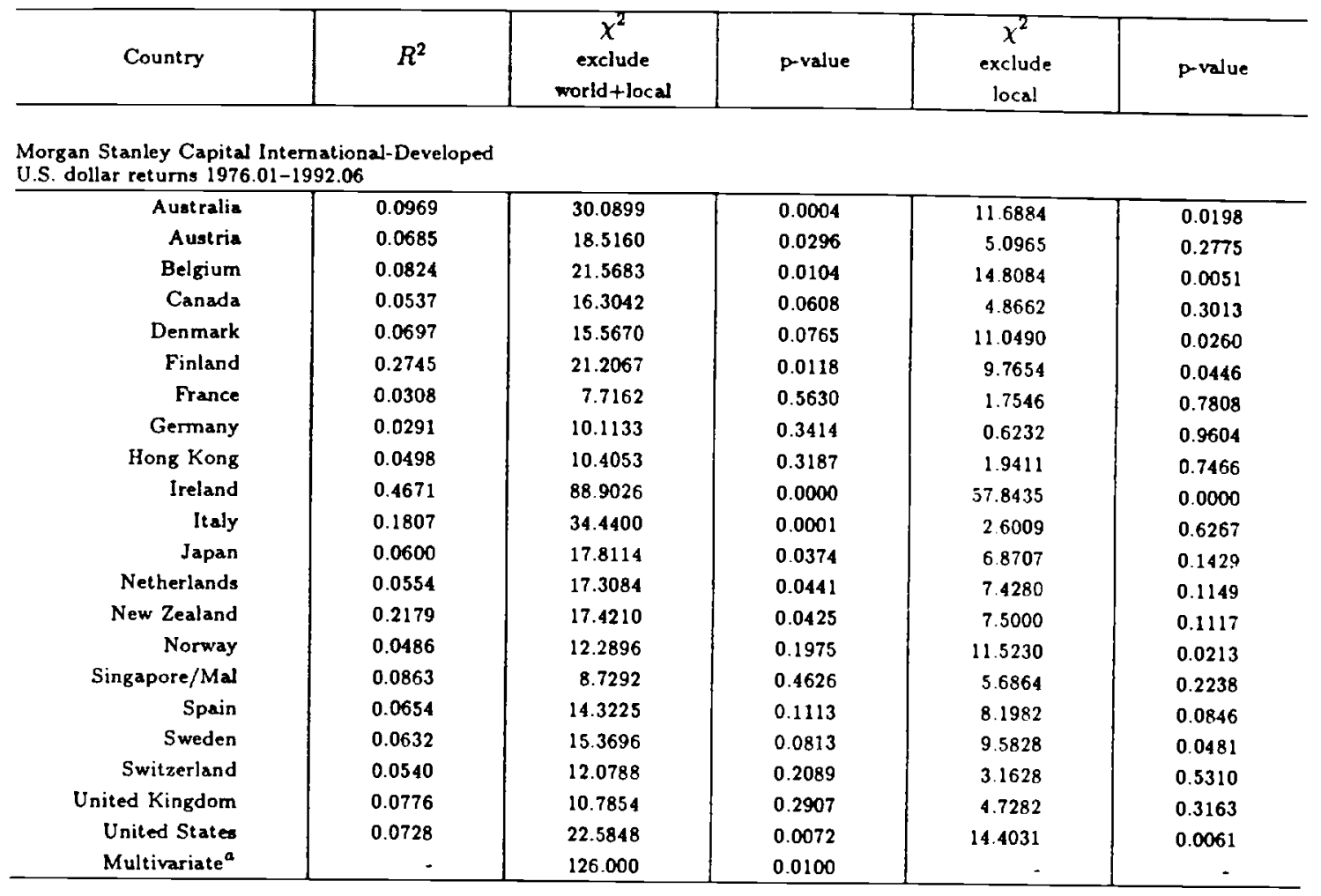

International Finance Corporation-Emerging

U.S. dollar returns 1976.01-1992.06

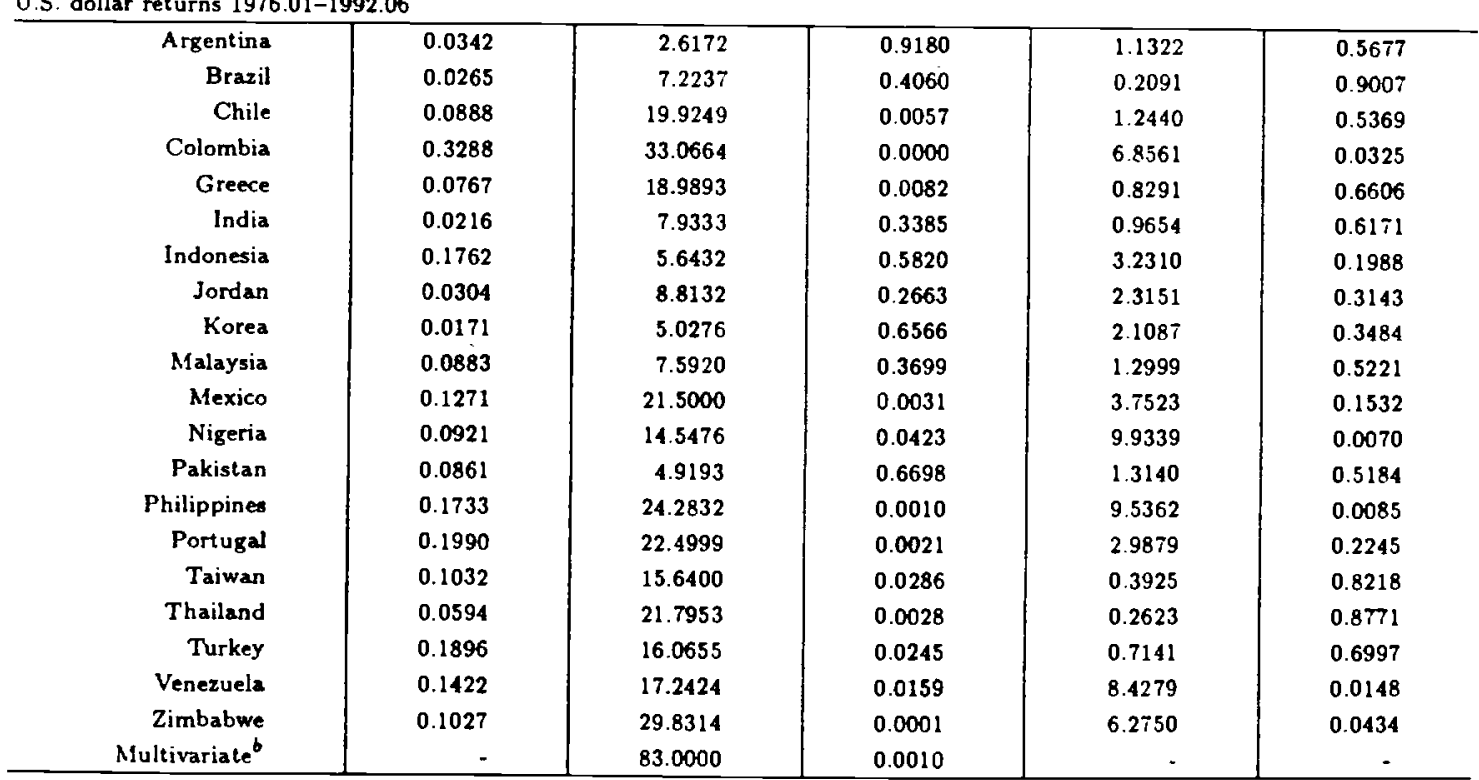


Table 5 (continued)

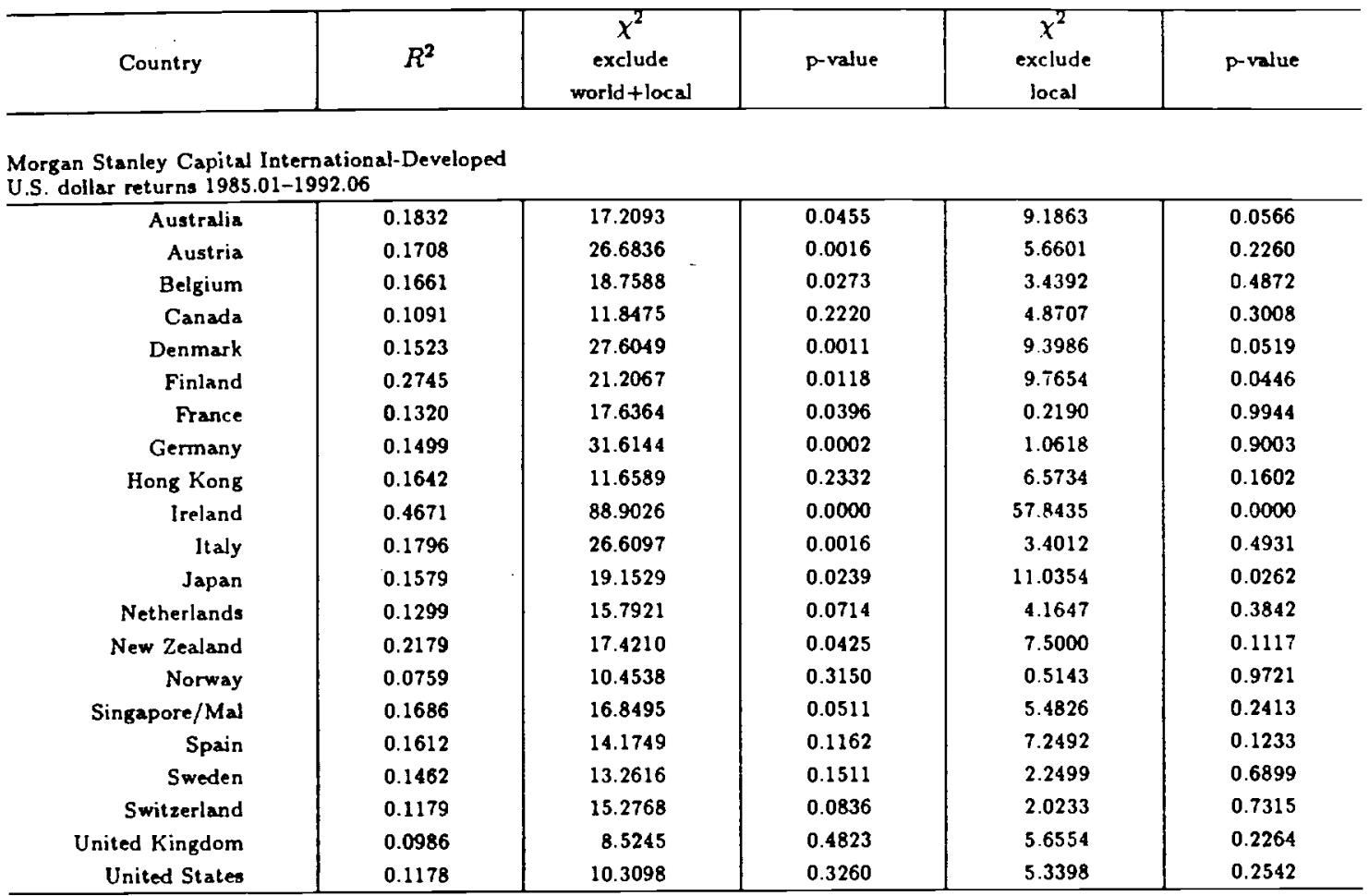

International Finance Corporation-Emerging U.S. dollar returns $1985.01-1992.06$

\begin{tabular}{r|r|r|r|r|r} 
Argentina & 0.1108 & 9.5080 & 0.3918 & 5.7453 & 0.2190 \\
Brazil & 0.0252 & 3.2560 & 0.9533 & 0.5554 & 0.9679 \\
Chile & 0.2428 & 39.0403 & 0.0000 & 13.6130 & 0.0086 \\
Colombia & 0.3787 & 59.7398 & 0.0000 & 25.5032 & 0.0000 \\
Greece & 0.1223 & 17.3832 & 0.0430 & 2.8725 & 0.5794 \\
India & 0.0570 & 6.2470 & 0.7150 & 4.4792 & 0.3450 \\
Indonesia & 0.6330 & 52.4884 & 0.0000 & 23.9739 & 0.0001 \\
Jordan & 0.1180 & 13.6932 & 0.1337 & 6.2785 & 0.1793 \\
Korea & 0.2176 & 37.7000 & 0.0000 & 18.4074 & 0.0010 \\
Malaysia & 0.1668 & 18.7800 & 0.0271 & 12.5749 & 0.0136 \\
Mexico & 0.2643 & 25.3075 & 0.0026 & 2.2255 & 0.6944 \\
Nigeria & 0.1468 & 10.3557 & 0.3225 & 8.7839 & 0.0667 \\
Pakistan & 0.1800 & 13.3439 & 0.1477 & 10.9778 & 0.0268 \\
Philippines & 0.3082 & 27.0724 & 0.0014 & 21.1182 & 0.0003 \\
Portugal & 0.2626 & 20.6209 & 0.0144 & 6.8722 & 0.1428 \\
Taiwan & 0.2712 & 32.2702 & 0.0002 & 7.1384 & 0.1288 \\
Thailand & 0.1187 & 7.0616 & 0.6307 & 3.3668 & 0.4984 \\
Turkey & 0.3372 & 22.8739 & 0.0065 & 4.3113 & 0.3655 \\
Venezuela & 0.2522 & 30.9940 & 0.0003 & 5.2139 & 0.2660 \\
Zimbabwe & 0.3372 & 42.3676 & 0.0000 & 12.8426 & 0.0121 \\
\hline
\end{tabular}

${ }^{a}$ Test results for $18 \mathrm{MSCl}$ countries (Finland, Ireland and New Zealand are not included since their data starts in 1987).

${ }^{h}$ Test results are for nine IFC countries: Argentina, Brazil. Chile, Greece, India, Korea, Mexico. Thailand, and Zimbabwe. The data for the other emerging markets begins later. 
Figure 3

Conditional asset allocation

A. Developed markels: no short sales
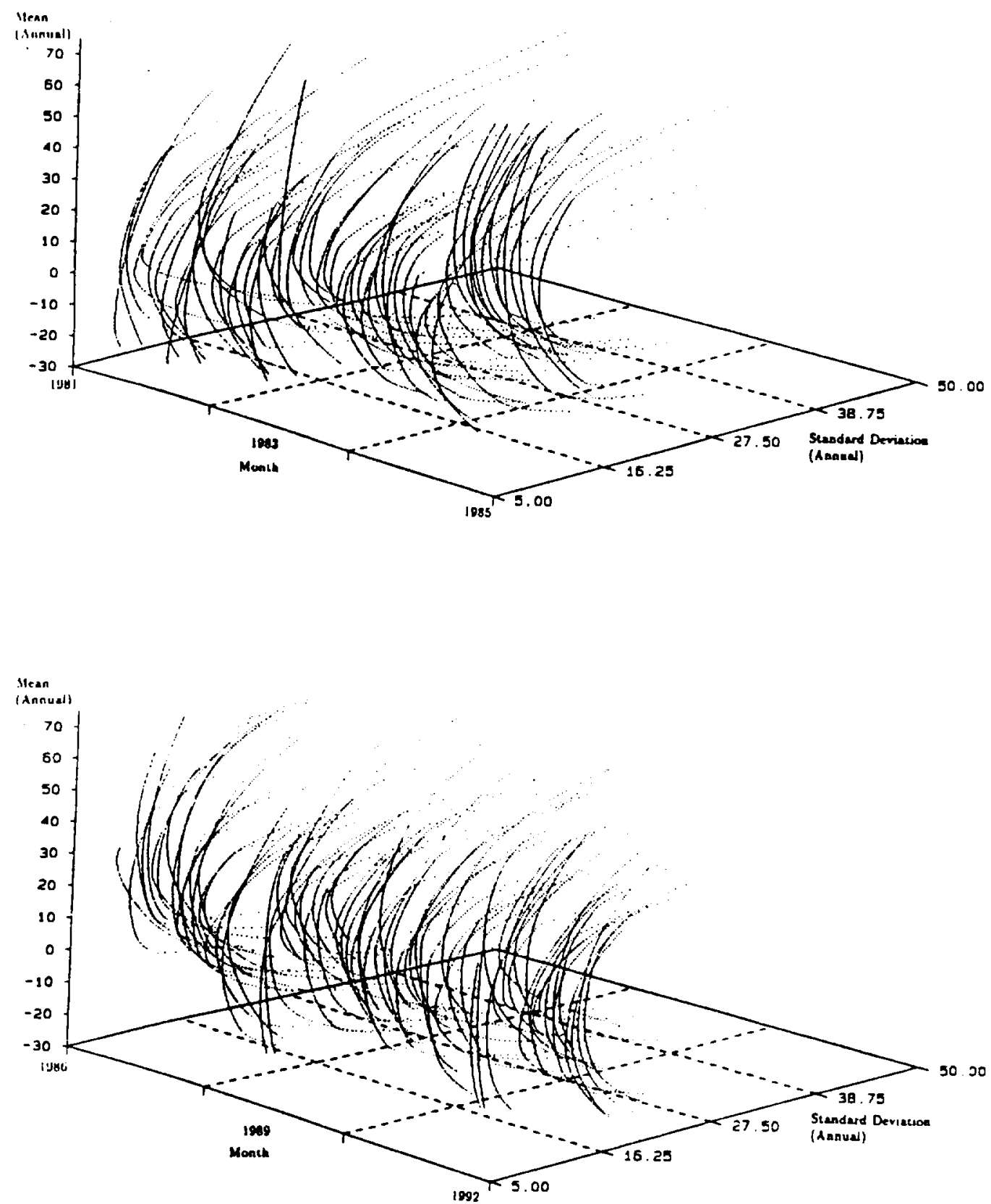
Figure 3 (continued)

B. Developed and emerging markets: no short sales
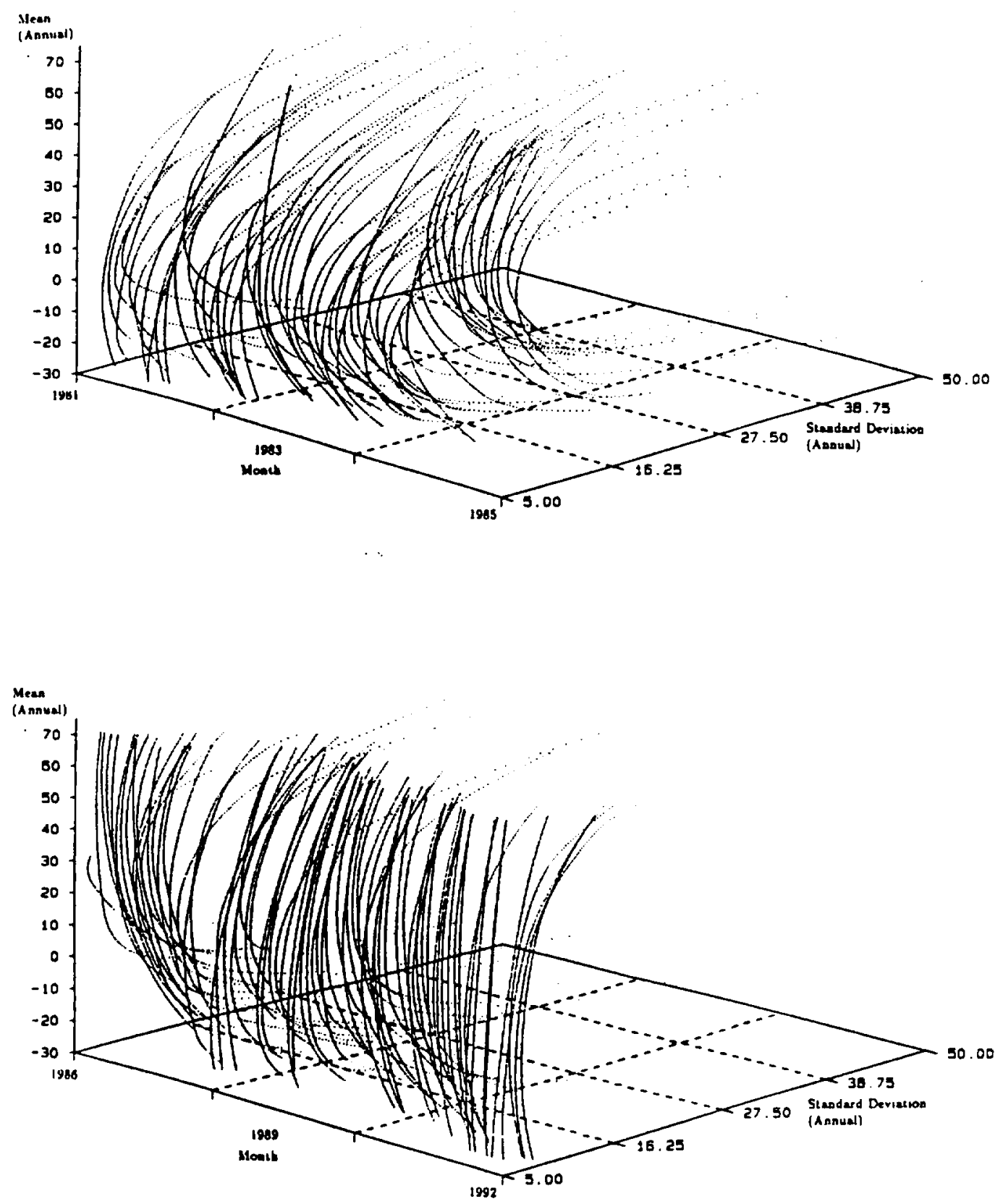
Figure 3 (continued)

C. Developed and emerging markets (20\% cap): no short sales
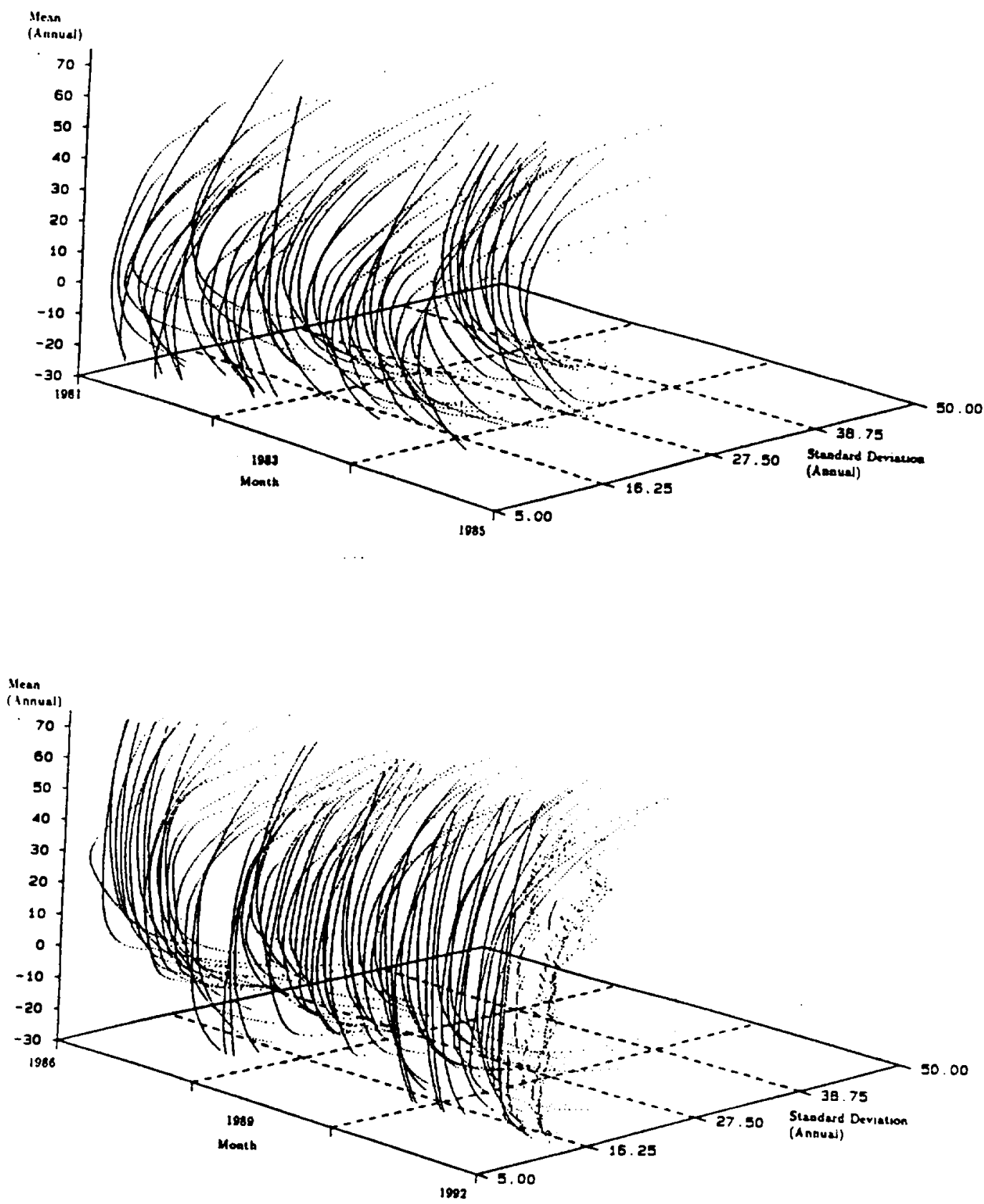
Figure 4

Conditional allocation investment weights

A. Kinimum volatility strategy

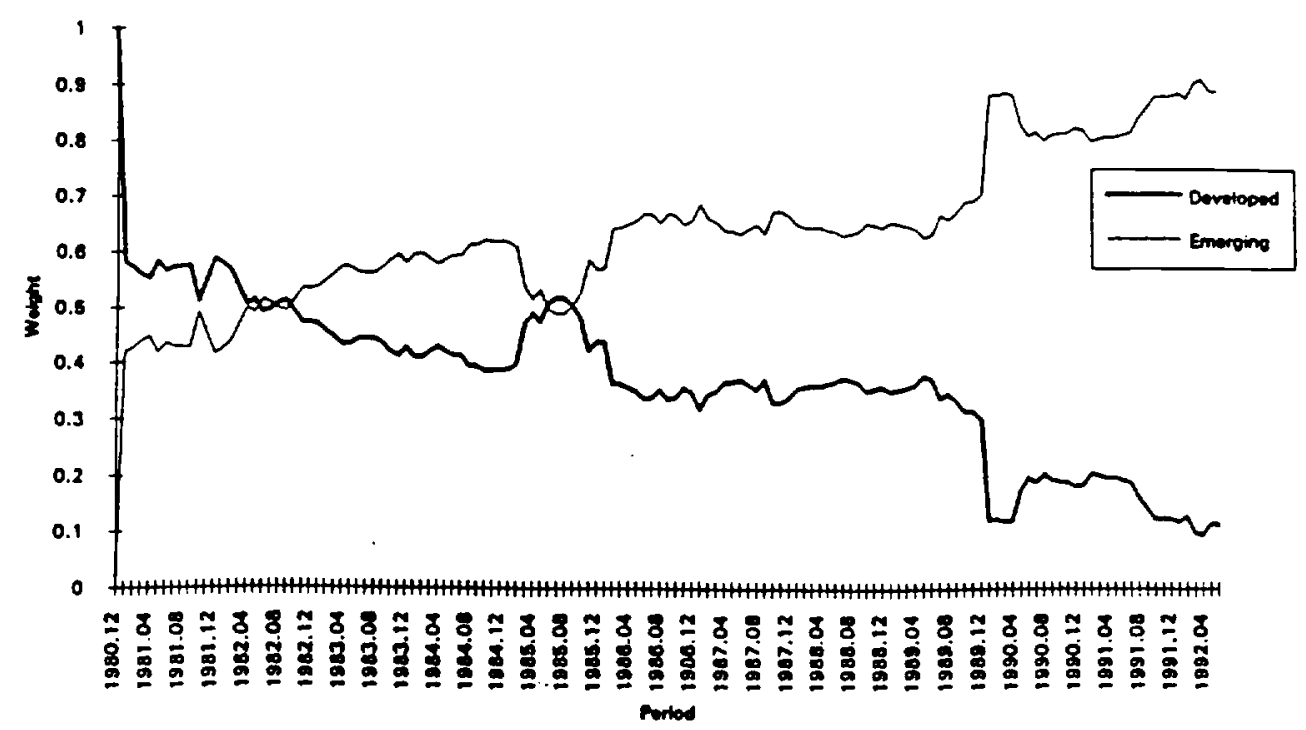

B. Kinimum volatility strategy with $20 \%$ emerging cap

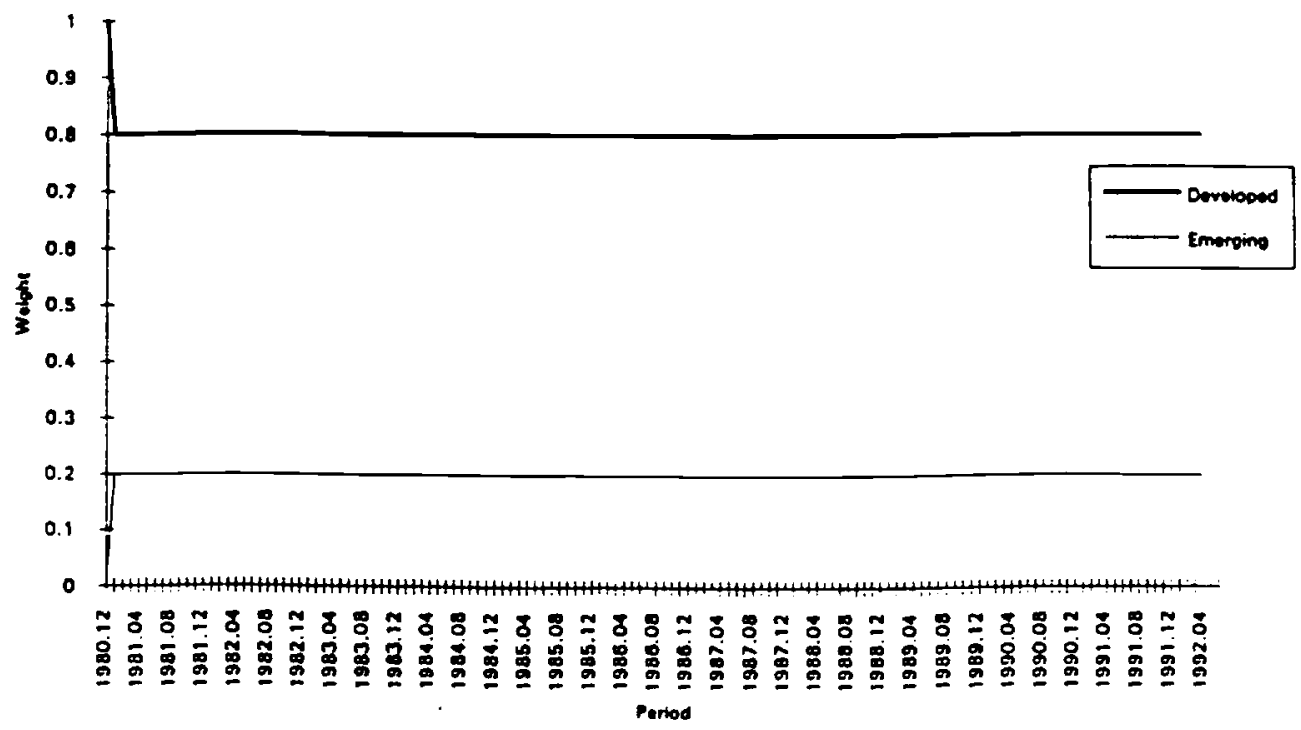


Figure 4 (continued)

C. Target volatility of $16 \%$ strategy

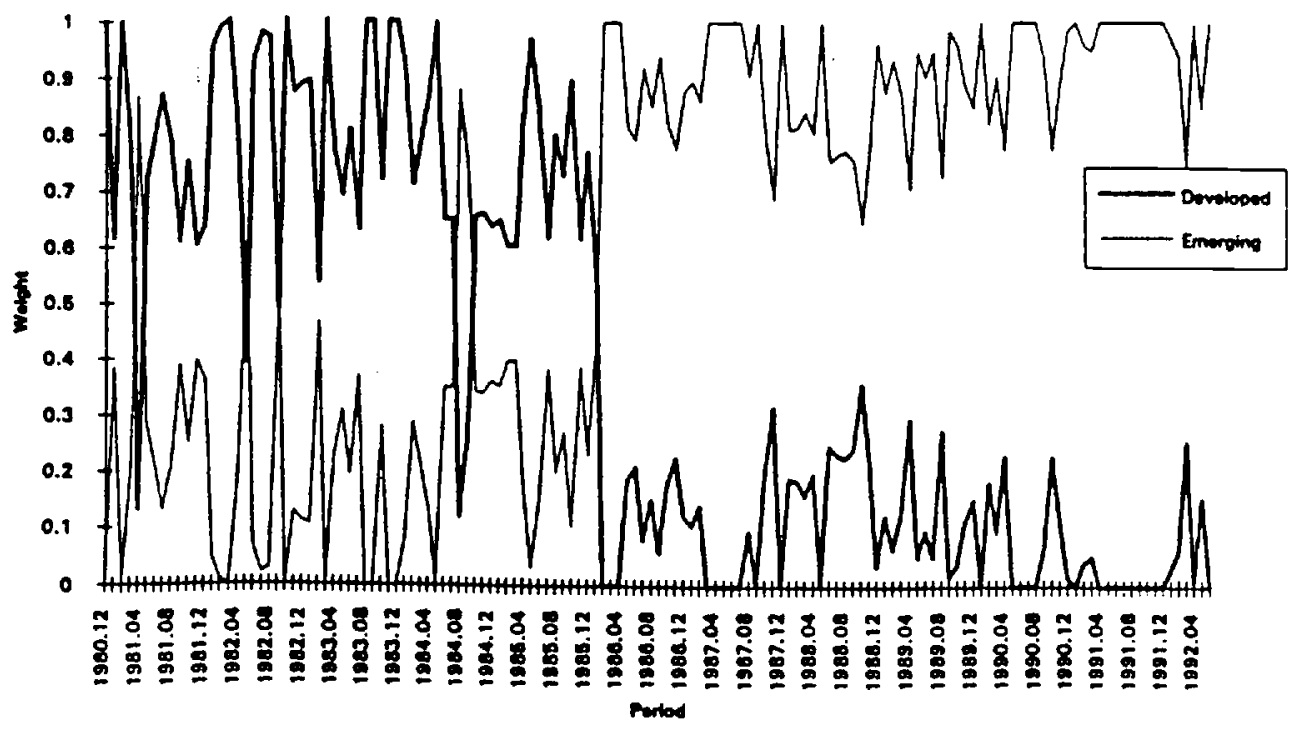

D. Target volatility of $16 \%$ strategy with $20 \%$ emerging cap

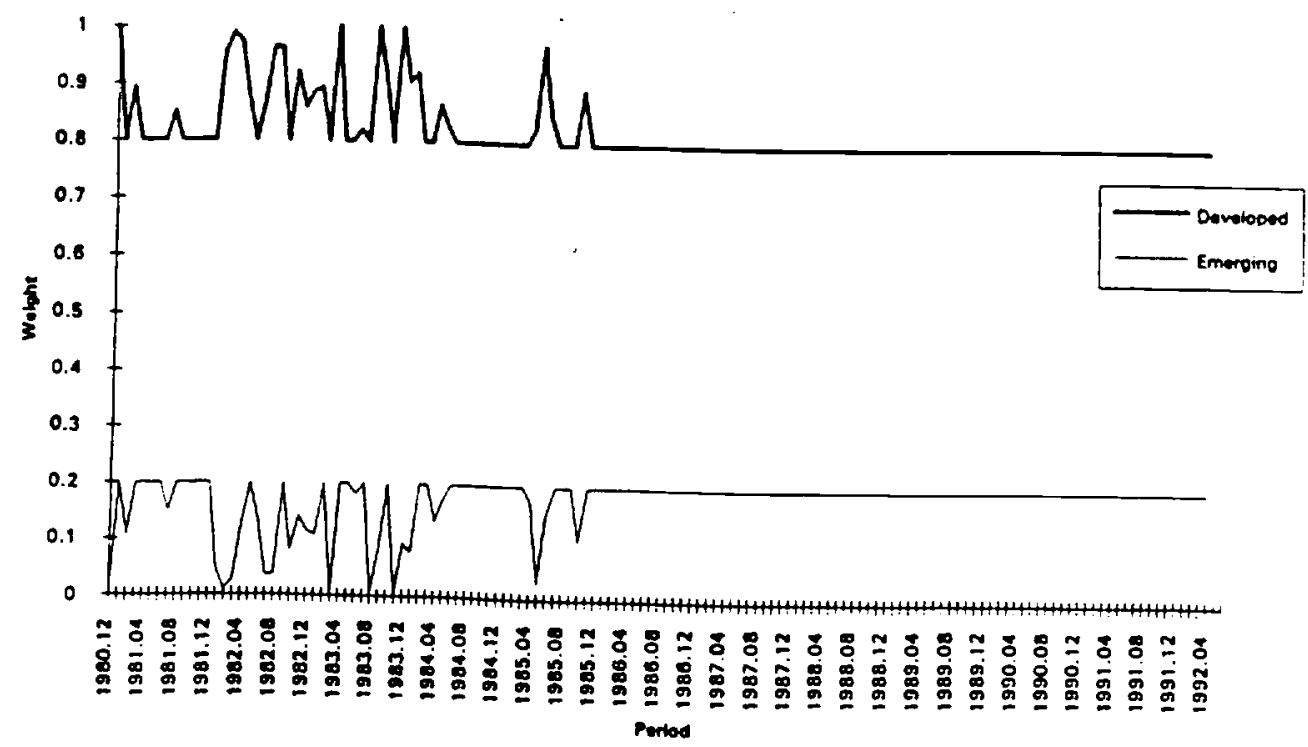


Table 6

Performance of Conditional Asset Allocation

\begin{tabular}{c|c|c|c|c|c|c}
\hline Universe & $\begin{array}{c}\text { Cumulative } \\
\text { retum }\end{array}$ & $\begin{array}{c}\text { Mean } \\
\text { return } \\
\text { (annualized) }\end{array}$ & $\begin{array}{c}\text { Standard } \\
\text { deviation } \\
\text { (annualized) }\end{array}$ & $\begin{array}{c}\text { Target } \\
\text { standard } \\
\text { deviation }\end{array}$ & Minimum & Maximum \\
\hline
\end{tabular}

Strategy: Choose minimum variance portfolio 1980.01-1992.06

\begin{tabular}{r|r|r|r|r|r|r|r|}
\hline Developed Countries & 195.42 & 16.99 & 15.14 & 11.12 & -25.86 & 12.86 \\
Developed/Emerging & 206.63 & 17.97 & 11.66 & 6.92 & -16.05 & 9.86 \\
Developed/Emerging 20\% cap & 215.47 & 18.87 & 14.05 & 9.01 & -22.10 & 12.07 \\
\hline
\end{tabular}

Strategy: Choose $16 \%$ target tandard devistion 1980.01-1992.06

\begin{tabular}{r|l|l|l|l|l|l|l|}
\hline $1980.01-1992.06$ & 344.36 & 29.94 & 18.33 & 16.23 & -16.25 & 12.37 \\
Developed Countries & 632.04 & 54.96 & 24.40 & 16.23 & -23.03 & 25.87 \\
Developed/Emerging & 638.67 & 39.30 & 19.89 & 15.99 & -18.67 & 19.27 \\
\hline Developed/Emerging 20\% cap & 488.67
\end{tabular}

All forecasts are in sample. The conditioning information includes: a constant, the lagged world return, the lagged return on the G-10 currency index, the lagged MSCI world dividend yield, the lagged world earnings price ratio, the Eurodollar rate, lagged lacal retum, lagged local exchange rate change, lagged country dividend yield and the lagged country earnings price ratio. The last two variables are only available from 1985. 
Table 7

Year by Year Performance of Conditional Asset Allocation

\begin{tabular}{|c|c|c|c|c|c|c|}
\hline \multirow[b]{2}{*}{ Year } & \multicolumn{3}{|c|}{ Choose minimum variance } & \multicolumn{3}{|c|}{ Choose $16 \%$ target volatility } \\
\hline & Developed & $\begin{array}{c}\text { Developed \& } \\
\text { Emerging }\end{array}$ & \begin{tabular}{|c|} 
Developed \&: \\
Emerging 20\% cap
\end{tabular} & Developed & $\begin{array}{c}\text { Developed \&z } \\
\text { Emerging }\end{array}$ & $\begin{array}{c}\text { Developed \& } \\
\text { Emerging } 20 \% \text { cap }\end{array}$ \\
\hline 1981 & 1.3018 & -5.8184 & -0.1670 & 3.8185 & 5.6710 & 32.9145 \\
\hline 1982 & 0.2946 & 1.4066 & 3.5112 & 7.6095 & 0.6140 & -0.4905 \\
\hline 1983 & 15.4399 & 14.8893 & 17.1995 & 31.3091 & 9.5892 & 7.0840 \\
\hline 1984 & 5.7125 & 4.9569 & 6.9219 & 40.0834 & 36.2280 & 36.8765 \\
\hline 1985 & 58.8476 & 51.0906 & 60.0647 & 93.9195 & 87.8920 & 94.8233 \\
\hline 1986 & 41.2669 & 42.5400 & 44.6026 & 46.0220 & 73.6191 & 49.9663 \\
\hline 1987 & 10.8734 & 1.6883 & 0.4706 & 15.9580 & 59.0413 & 6.3606 \\
\hline 1988 & 0.3374 & 17.0633 & 17.7711 & 7.1674 & 44.6962 & 6.7234 \\
\hline 1989 & 34.2864 & 7.2271 & 33.1377 & 36.6910 & 69.4644 & 59.6868 \\
\hline 1990 & -7.5366 & 19.0070 & 12.6248 & -2.5873 & 65.4862 & 7.0179 \\
\hline 1991 & 16.8578 & 5.4892 & 7.9483 & 7.0525 & 132.8474 & 59.9122 \\
\hline 1992 & -4.2582 & -12.9065 & -8.6191 & -2.6816 & 4.8951 & 7.7893 \\
\hline
\end{tabular}

All forecasts are in sample. The conditioning information includes: a constant, the lagged world return, the lagged return on the G-10 currency index, the lagged MSCI world dividend yield, the lagged world earnings price ratio, the Eurodollar rate, lagged local return, lagged local exchange rate change, lagged country dividend yield and the lagged country earnings price ratio. The last two variables are only available from 1985 . 
Table 8

Performance of Conditional Asset Allocation Strategies Using Out-of-Sample Forecasts

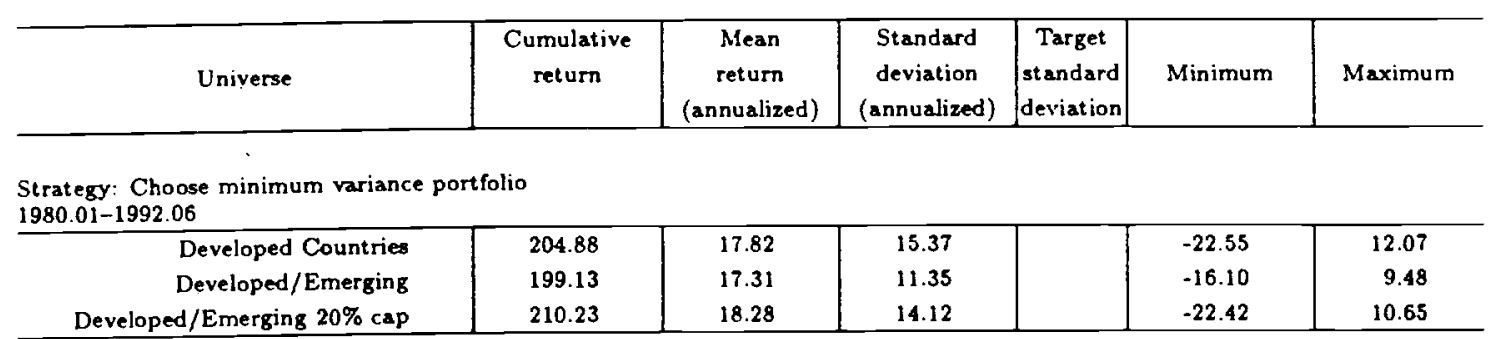

Strategy: Choose $16 \%$ target standard deviation 1980.01-1992.06

\begin{tabular}{|c|l|l|l|l|l|l|}
\hline Developed Countries & 190.49 & 16.56 & 18.64 & & -22.58 & 13.47 \\
Developed/Emerging & 292.48 & 25.43 & 19.23 & & -25.75 & 18.75 \\
Ded/Emerging 20\% cap & 232.87 & 20.25 & 19.20 & & -26.58 & 19.41 \\
\hline
\end{tabular}

Developed/Emerging 20\% cap

Based on out-of-sample forecasts. The conditioning variables include: a constant, lagged world return, lagged change in G-10 exchange rate, lagged world dividend yield, the lagged world earnings-price ratio, the Eurodollar rate, and the lagged country return. 
Table 9

Year by Year Performance of Conditional Asset Allocation Using Out-of-Sample Forecasts

\begin{tabular}{c|c|c|c|c|c|c}
\hline \multirow{2}{*}{ Year } & \multicolumn{3}{|c|}{ Choose minimum variance } & \multicolumn{3}{c}{ Choose 16\% target volatility } \\
& Developed & $\begin{array}{c}\text { Developed \& } \\
\text { Emerging }\end{array}$ & $\begin{array}{c}\text { Developed \& } \\
\text { Emerging 20\% cap }\end{array}$ & Developed & $\begin{array}{c}\text { Developed \& } \\
\text { Emerging }\end{array}$ & $\begin{array}{c}\text { Developed \& } \\
\text { Emerging 20\% cap }\end{array}$ \\
\hline 1981 & -4.61 & -2.38 & -3.07 & 1.11 & -7.60 & -8.79 \\
1982 & 0.97 & 3.42 & 3.57 & -16.79 & -17.73 & -12.40 \\
1983 & 12.80 & 10.60 & 13.84 & 39.57 & 36.60 & 41.10 \\
1984 & 8.90 & 6.45 & 9.95 & -13.68 & -7.72 & -15.02 \\
1985 & 59.71 & 40.29 & 57.52 & 51.51 & 54.15 & 53.53 \\
1986 & 39.81 & 42.87 & 42.05 & 50.35 & 41.48 & 52.17 \\
1987 & 19.04 & 22.87 & 23.91 & 18.63 & 30.58 & 32.73 \\
1988 & 23.60 & 16.59 & 18.43 & 21.44 & 35.91 & 24.77 \\
1989 & 36.50 & 26.78 & 33.71 & 29.26 & 25.98 & 24.42 \\
1990 & -6.13 & 14.96 & 9.43 & -9.32 & 23.43 & 1.64 \\
1991 & 18.22 & 26.16 & 14.36 & 17.61 & 72.72 & 35.33 \\
1992 & -3.96 & -9.51 & -13.51 & 0.80 & 4.66 & 3.36 \\
\hline
\end{tabular}

Based on out-of-sample forecasts. The conditioning variables include: a constant, lagged world retum, lagged change in G-10 exchange rate, lagged world dividend yield, the lagged world earnings-price ratio, the Eurodollar rate, and the lagged country ret ur There are only six out-of-sample forecasts for 1992 . 